Received: 20 December 2017

Accepted: 19 October 2018

Published online: 02 November 2018

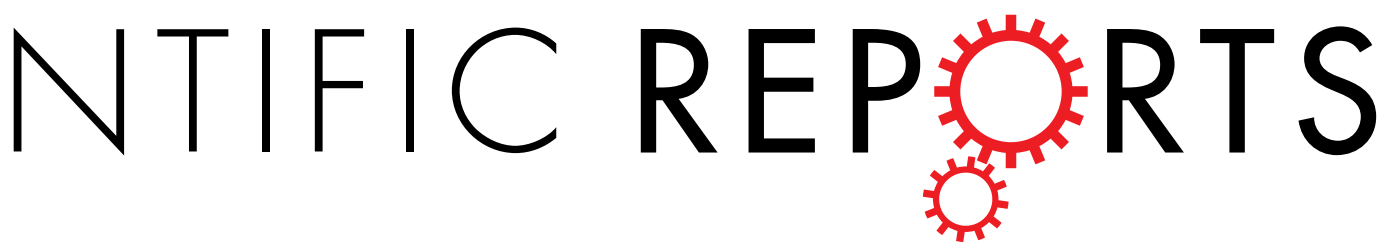

\title{
Antimicrobial Activities and
}

\section{Mechanisms of Magnesium Oxide Nanoparticles (nMgO) against Pathogenic Bacteria, Yeasts, and Biofilms}

\author{
Nhu-Y Thi Nguyen ${ }^{1}$, Nathaniel Grelling ${ }^{2}$, Cheyann Lee Wetteland ${ }^{2}$, Romeo Rosario ${ }^{2}$ \& \\ Huinan Liu $\mathbb{D}^{1,2,3}$
}

Magnesium oxide nanoparticle (nMgO) is a light metal based antimicrobial nanoparticle that can be metabolized and fully resorbed in the body. To take advantage of the antimicrobial properties of $\mathrm{nMgO}$ for medical use, it is necessary to determine the minimal inhibitory, bactericidal and fungicidal concentrations (MIC, MBC and MFC) of $\mathrm{nMgO}$ against prevalent infectious bacteria and yeasts. The objective of this study was to use consistent methods and conditions to reveal and directly compare the efficacy of $\mathrm{nMgO}$ against nine prevalent pathogenic microorganisms, including two gram-negative bacteria, three gram-positive bacteria with drug-resistant strains, and four yeasts with drug-resistant strains. The MIC of $\mathrm{nMgO}$ varied from $0.5 \mathrm{mg} / \mathrm{mL}$ to $1.2 \mathrm{mg} / \mathrm{mL}$ and the minimal lethal concentration (MLC) of $\mathrm{nMgO}$ at $90 \%$ killing varied from $0.7 \mathrm{mg} / \mathrm{mL}$ to $1.4 \mathrm{mg} / \mathrm{mL}$ against different pathogenic bacteria and yeasts. The most potent concentrations (MPC) of $\mathrm{nMgO}$ were $1.4 \mathrm{and} / \mathrm{or} 1.6 \mathrm{mg} / \mathrm{mL}$, depending on the type of bacteria and yeasts tested. As the concentration of $\mathrm{nMgO}$ increased, the adhesion of bacteria and yeasts decreased. Moreover, S. epidermidis biofilm was disrupted at $1.6 \mathrm{mg} / \mathrm{mL}$ of $\mathrm{nMgO}$. E. coli and some yeasts showed membrane damage after cultured with $\geq 0.5 \mathrm{mg} / \mathrm{mL} \mathrm{nMgO}$. Overall, nMgO killed both planktonic bacteria and disrupted nascent biofilms, suggesting new antimicrobial mechanisms of $\mathrm{nMgO}$. Production of reactive oxygen species (ROS), $\mathrm{Ca}^{2+}$ ion concentrations, and quorum sensing likely contribute to the action mechanisms of $\mathrm{nMgO}$ against planktonic bacteria, but transient alkaline $\mathrm{pH}$ of 7 to 10 or increased $\mathrm{Mg}^{2+}$ ion concentrations from 1 to $50 \mathrm{mM}$ showed no inhibitory or killing effects on bacteria such as $S$. epidermidis. Further studies are needed to determine if specific concentrations of nMgO at MIC, MLC or MPC level can be integrated into medical devices to evoke desired antimicrobial responses without harming host cells.

Infection is a major clinical complication associated with implanted medical devices, which costs 5-10 billion dollars per year to treat, prolongs the hospital stay, and causes clinical complications for patients ${ }^{1}$. Sixty to seventy percent of all nosocomial (hospital-acquired) infections involve biofilms, and biofilms are 1000-fold more resistant to antibiotics than planktonic bacteria ${ }^{2,3}$. Systemically administered antibiotics and antifungals are used to treat infections, but they often cannot penetrate biofilms and more bacteria and fungi become drug resistant ${ }^{4,5}$. Once infected, the medical devices and implants often require a secondary surgery or procedure for removal, which increases healthcare cost and discomfort for patients ${ }^{6-8}$. Considering that insurance programs such as Medicare ceased payments for hospital-acquired infections in $2008^{9}$, the costs for hospitals and patients further escalated.

New biomaterials are critically needed to reduce or eliminate microbial adhesion and infections, thus minimizing the use of antibiotics and emergence of antibiotic-resistant strains and mitigating infections of medical devices. Many nanoparticles such as silver nanoparticles, zinc oxide $(\mathrm{ZnO})$ nanoparticles, and titanium oxide

${ }^{1}$ Microbiology Graduate Program, University of California, Riverside, CA, 92521, USA. ${ }^{2}$ Department of Bioengineering, University of California, Riverside, CA, 92521, USA. ${ }^{3}$ Materials Science and Engineering Program, University of California, Riverside, CA, 92521, USA. Correspondence and requests for materials should be addressed to H.L. (email: huinan.liu@ucr.edu) 
$\left(\mathrm{TiO}_{2}\right)$ nanoparticles have shown antimicrobial properties against a broad spectrum of microorganisms ${ }^{10-13}$. However, these nanoparticles cause significant concerns regarding their toxicity due to the risks associated with heavy metal elements and their accumulation in the body. In contrast, magnesium oxide nanoparticles (abbreviated as $\mathrm{nMgO}$ ) is an attractive alternative to heavy metal based nanoparticles such as silver and $\mathrm{ZnO}$, because $\mathrm{nMgO}$ can be degraded and metabolized efficiently in the body, and the released degradation products of $\mathrm{Mg}^{2+}$ and $\mathrm{OH}^{-}$ions can be effectively eliminated from the body as long as renal function is normal, thus removing the concerns of excessive metal accumulation in the body.

Previously, $\mathrm{MgO}$ nanoparticles ( $\mathrm{nMgO}$ ) have been reported to inhibit gram-positive, gram-negative, and endospore-forming bacteria ${ }^{14-18}$. Tang et al. have reviewed $\mathrm{MgO}$ nanoparticles as antibacterial agent ${ }^{19}$. However, there are no standards established for testing the antimicrobial properties of nanoparticles. Thus, different experimental techniques were used, $\mathrm{MgO}$ with varying sizes and concentrations were studied, and different initial seeding densities of bacteria were used in the previous studies on antimicrobial properties of $\mathrm{MgO}$. These experimental differences do affect the results significantly, which made the previous results not directly comparable with one another and not directly applicable for designing antimicrobial medical devices. Even though the previous studies did prove that $\mathrm{MgO}$ had antibacterial properties under different conditions, the antimicrobial potency of $\mathrm{nMgO}$ is still unknown and incomparable against a wide spectrum of pathogenic microorganisms. It is necessary to establish consistent conditions in order to directly compare the effects of the same nMgO dosages on a wide range of clinically relevant microorganisms. In order to take full advantage of nMgO toward potential clinical translation to broad medical applications, a consistent method was established in this study and used to determine the efficacy of $\mathrm{nMgO}$ against different microorganisms. Under the consistent conditions, we investigated and directly compared the effects of $\mathrm{nMgO}$ on nine different types of pathogenic microorganisms in planktonic forms or biofilms, including gram-negative bacteria, gram-positive bacteria, yeasts, and their resistant strains. According to our literature search, this is the first study to use the same well-defined and consistent method to quantify and directly compare antimicrobial activities of $\mathrm{nMgO}$ against five major infectious bacteria with drug resistant strains, four yeasts with drug resistant strains, and nascent biofilms. Moreover, this is the first time to study the $\mathrm{nMgO}$ activity against Candida glabrata (C. glabrata), an organism that has been gaining resistance to multiple widely-used antifungals ${ }^{20}$.

The first objective of this study was to use the consistent method to examine, quantify and compare the concentration effects of $\mathrm{nMgO}$ against the following microorganisms. Specifically, two gram-negative bacteria include Escherichia coli (E. coli) and Pseudomonas aeruginosa ( $P$. aeruginosa); three gram-positive bacteria include Staphylococcus epidermidis (S. epidermidis), Staphylococcus aureus (S. aureus), and methicillin-resistant Staphylococcus aureus (MRSA); and four infectious yeasts include drug-sensitive Candida albicans (C. albicans), Fluconazole resistant Candida albicans (C. albicans FR), drug-sensitive Candida glabrata (C. glabrata), and echinocandin resistant Candida glabrata (C. glabrata ER). The minimal inhibitory concentration (MIC) of any antibiotic or antifungal drugs is the lowest concentration required to inhibit visible growth of a microorganism in culture. The minimal lethal concentration (MLC) is the lowest concentration of any antibiotic or antifungal drugs required to kill a microorganism in culture, that is, no growth of the microorganism even when it is sub-cultured subsequently in drug-free media ${ }^{21}$. The minimal bactericidal or fungicidal concentration (MBC or MFC) is the MLC for bacteria or yeasts respectively, i.e., the lowest concentration required to kill a respective bacterium or fungus in culture. MBC and MFC are generally considered as the dosage at which $99.9 \%$ of bacteria or yeasts are killed $^{22}$, however, some also used $90 \%$ of death as a cut off ${ }^{23,24}$. The same concept of MIC, MLC, MBC, and MFC was adapted for the respective concentrations of $\mathrm{nMgO}$ in this article. However, it is important to mention that $\mathrm{MgO}$ is not considered as an antibiotic or antifungal drug. The $\mathrm{MLC}_{90}, \mathrm{MLC}_{99}, \mathrm{MLC}_{99.9}$, and $\mathrm{MLC}_{99.99}$ were used in this article to refer to the MBC or MFC of nMgO that killed $90 \%, 99 \%, 99.9 \%$ or $99.99 \%$ of bacteria or yeasts during 24 hours of culture in vitro.

The nine microorganisms above were chosen because they are prevalent pathogenic species isolated from infected medical devices and represent a large variety of bacteria and yeasts, including the drug-resistant strains $s^{6,25,26}$. Drug resistant strains are included in this study because they are major threats in the health care, and it is clinically important to determine and compare the efficacy of $\mathrm{nMgO}$ against the antibiotic/antifungal resistant microorganisms. The concentrations of $\mathrm{nMgO}$ between $0.2 \mathrm{mg} / \mathrm{mL}$ and $2.0 \mathrm{mg} / \mathrm{mL}$ were chosen because this range covered different concentrations that have shown antimicrobial activities in the literature $\mathrm{e}^{15,17,18,27}$. The concentrations of $\mathrm{nMgO}$ below $0.2 \mathrm{mg} / \mathrm{mL}$ were not included in this study because the lower concentrations have no detectable antimicrobial effects on the microbes of interest. Moreover, Wetteland $e t$ al. studied the interactions of $0.2-2.0 \mathrm{mg} / \mathrm{mL} \mathrm{nMgO}$ with bone marrow derived mesenchymal stem cells (BMSCs) ${ }^{18}$; and the same concentration range of $\mathrm{nMgO}$ was used against microbes in this study in order to compare with the previous results. Since planktonic bacteria have to adhere to a material or medical device to initiate an infection, the second objective was to evaluate the adhesion and morphologies of different microorganisms after they were cultured with $0-2.0 \mathrm{mg} / \mathrm{mL}$ of $\mathrm{nMgO}$. Considering that the established biofilms are much harder to treat, the third objective was to determine if the $\mathrm{nMgO}$ can disrupt a model biofilm of $S$. epidermidis at the concentration of $\mathrm{nMgO}$ that showed the highest potency against S. epidermidis. The possible interaction mechanisms of nMgO with these pathogenic bacteria, yeasts, and biofilms were discussed.

\section{Materials and Methods}

Prepare and Characterize MgO nanoparticles (nMgO). $\mathrm{MgO}$ nanoparticles (nMgO; US Research Nanomaterials Inc.) had a purity of $99+\%$, with an average diameter of $20 \mathrm{~nm}$ and polyhedral morphology. $\mathrm{MgO}$ has a true density of $3.58 \mathrm{~g} / \mathrm{cm}^{3}$. For this study, $\mathrm{MgO}$ nanoparticles were sterilized through heating in an oven at $200^{\circ} \mathrm{C}$ for one hour before each in vitro experiment, because other methods of sterilization or disinfection are not suitable for $\mathrm{nMgO}$. Specifically, $\mathrm{nMgO}$ is hygroscopic; and, thus, autoclaving is not an ideal method for sterilization, because the water in the steam causes phase change, which affects the accuracy of experimental 
results against microorganisms. Furthermore, $\mathrm{nMgO}$ absorbs ultraviolet (UV) light and interacts with oxygen molecules ${ }^{18,28}$; and, thus, UV should not be used to disinfect the $\mathrm{nMgO}$ nanoparticles.

$\mathrm{MgO}$ nanoparticles were characterized using scanning electron microscopy (SEM, Nova NanoSEM 450) and transmission electron microscopy (TEM, Titan Themis 300). The particle size and distribution were analyzed using the quantitative tools in the ImageJ software. Elemental composition and phase of these nanoparticles were confirmed using energy dispersive $x$-ray spectroscopy (EDS, EDAX Leap detector attached to Nova NanoSEM), and $x$-ray diffraction (XRD, Model D8/Advanced, Bruker), respectively.

The zeta potential of $\mathrm{nMgO}$ in water was measured following a method adapted from Tian et al..$^{29}$. Briefly, a zeta potential and submicron particle size analyzer (Delsa ${ }^{\mathrm{TM}}$ Nano C, Beckman Coulter) was used to determine the zeta potential of nMgO. Water was used as the diluent, which had a refractive index of 1.33 , viscosity of $0.89 \mathrm{cP}$, and dielectric constant of 78.3. The test was carried out at the room temperature of $25^{\circ} \mathrm{C}$ with an applied potential of $5 \mathrm{~V} / \mathrm{cm}$, and was repeated for three times. The electrical mobility of $\mathrm{nMgO}$ was measured based on the frequency shift of the scattered light using the Laser Doppler method, and the zeta potential of $\mathrm{nMgO}$ was calculated according to Huckel equation.

Bacterial and yeast cultures. The stocks of P. aeruginosa, S. aureus, MRSA, C. albicans, C. albicans FR, C. glabrata and C. glabrata ER were generously provided by Dr. Jill P. Adler-Moore from California State Polytechnic University, Pomona.

Culture methods for gram-positive and gram-negative bacteria. Frozen stocks of E. coli (ATCC 25922) and Pseudomonas aeruginosa (P. aeruginosa) (ATCC 29260) were retrieved from the $-80^{\circ} \mathrm{C}$ freezer, and cultured in Luria Bertani Broth (LBB; Sigma Life Science, Sigma-Aldrich) and Tryptic Soy Broth (TSB; Fluka Analytical, Sigma-Aldrich), respectively. Five milliliters of the frozen stock were cultured in $30 \mathrm{~mL}$ of the respective broth for 16 hours in a shaker incubator (Benchmark Incu-shaker $10 \mathrm{~L}, \mathrm{VWR}$ ) at $37^{\circ} \mathrm{C}$ and $250 \mathrm{rpm}$. The concentrations of $E$. coli and P. aeruginosa were determined by counting bacteria with a hemocytometer (Brightline, Hausser Scientific) and they were diluted to $7.8 \times 10^{6}$ cells $/ \mathrm{mL}$ in LBB or TSB.

Similarly, frozen stocks of S. epidermidis (ATCC 35984), S. aureus (ATCC 25923), and MRSA (ATCC 33591) were retrieved and cultured in TSB overnight in a shaker incubator at $37^{\circ} \mathrm{C}$ and $250 \mathrm{rpm}$. The next day, $100 \mu \mathrm{L}$ of the culture was added into $5 \mathrm{~mL}$ of fresh TSB, and this culture was incubated for additional $4-6$ hours at $37^{\circ} \mathrm{C}$. After that, the concentrations of bacteria were determined using a hemocytometer and they were diluted to $7.8 \times 10^{6}$ cells $/ \mathrm{mL}$ using TSB.

Culture methods for drug-sensitive and drug-resistant yeasts. Frozen stocks of C. albicans (CP 620) and C. albicans FR (CP 714) were placed into Sabouraud Dextrose broth (Sab; Difco, VWR) in a $50 \mathrm{~mL}$ centrifuge tube. Five milliliters of the yeasts from the stock were cultured in $30 \mathrm{~mL}$ of Sab for 22 hours at $37^{\circ} \mathrm{C}$. After 22 hours, $2 \mathrm{~mL}$ of yeasts were transferred to $30 \mathrm{~mL}$ fresh Sab and cultured for 20 hours at room temperature. After that, $2 \mathrm{~mL}$ of yeast was transferred again to fresh Sab and cultured for 16 hours at room temperature. Three days of culture in different conditions ensured that yeast cells were in the single-cell form and did not have pseudohyphae at the start of each in vitro experiment. Pseudohyphae are long chains of budding yeast daughter cells that did not totally separate from the mother cells, mimicking a hyphae ${ }^{30}$.

Frozen stocks of C. glabrata (ATCC 90030) and C. glabrata ER (17351) were also cultured in Sab broth. They were incubated for 24 hours at $37^{\circ} \mathrm{C}$ without subsequent subculture. It was not necessary to subculture these yeasts because C. glabrata does not form pseudohyphae.

Prescribed seeding density of $7.8 \times 10^{6}$ cells $/ \mathrm{mL}$ for the bacteria and yeasts of interest. Each bacterial strain was cultured to the exponential phase as described above. In order to determine the concentration of respective microorganism in the broth before each in vitro experiment, the bacteria and yeasts were counted using a hemocytometer $^{31,32}$. For this purpose, each culture was diluted to 1:100 using a Tris(hydroxymethyl)aminomethane buffer (Tris buffer; Acros, Sigma-Aldrich). Ten microliters of the diluted bacterial suspension were loaded onto each side of the hemocytometer. The suspension was left to settle for 2 to 3 minutes for motile bacteria such as $E$. coli and $P$. aeruginosa. The bacteria were counted in the regions of the 25 squares in the center of hemocytometer using a compound microscope (VEEVanGuard, Biosciences) at a magnification of 400x. Only four corner squares and the center square were counted. After both sides of the hemocytometer were counted, the following equation was used to calculate the bacterial density:

$$
\begin{aligned}
\text { Bacterial density }= & \text { (bacterial counts on both sides of the hemocytometer } \\
& / 2)(5)(\text { dilution factor })\left(10^{4} \mathrm{~mL}\right)
\end{aligned}
$$

The next step was to dilute the bacteria to the desired concentration of $7.8 \times 10^{6}$ cells $/ \mathrm{mL}$ using either LBB or TSB according to $\mathrm{C}_{1} \mathrm{~V}_{1}=\mathrm{C}_{2} \mathrm{~V}_{2}$ equation. This was the working stock for in vitro experiments.

Counting yeasts was similar as counting bacteria, except one additional step. Yeasts are eukaryotic cells, and are much larger than bacteria. We used methylene blue stain (Fisher Chemicals, Fisher Scientific) to make sure we only counted live yeast cells. After the yeasts were cultured to the exponential phase, they were diluted to 1:5 using a Tris buffer and $20 \mu \mathrm{L}$ of methylene blue stain. The counting and calculation were the same as described above for the bacteria. The yeasts were diluted with Sab to the desired concentration of $7.8 \times 10^{6}$ cells $/ \mathrm{mL}$ for all in vitro experiments. The seeding density for yeasts was the same as for bacteria in order to directly compare the results between bacteria and yeasts. 
Verify the actual seeding density used for each microorganism of interest. After the bacteria and yeasts were diluted to the desired concentrations of $7.8 \times 10^{6} \mathrm{cells} / \mathrm{mL}$, an extra step was taken to confirm the actual seeding density for each microorganism. Each of the working stocks of bacteria or yeasts was plated onto its respective agar plate, either Luria Bertani agar (LB agar; Sigma Aldrich), Tryptic soy agar (TSA; Fluka Analytical, Sigma Aldrich) or Sabouraud agar (Sab agar; Gibco, VWR). All of the working stocks were diluted in a series of tenfold dilutions to reach $10^{-4}$, and $100 \mu \mathrm{L}$ was plated onto the agar. These plates were incubated at $37^{\circ} \mathrm{C}$ for 24 hours, and the colony forming units (CFU) on the plates were counted to calculate the actual seeding density. The prescribed seeding density of $7.8 \times 10^{6}$ cells $/ \mathrm{mL}$ was based on the counting with the hemocytometer, but the actual seeding density fluctuated between $6 \times 10^{6}$ and $8 \times 10^{6} \mathrm{CFU} / \mathrm{mL}$ as determined by the actual counting of CFUs on the respective agar plates.

Determine the concentration effects of $\mathrm{nMgO}$ against the bacteria and yeasts of interest. Culture bacteria and yeasts with $0.2 \mathrm{mg} / \mathrm{mL}$ to $2.0 \mathrm{mg} / \mathrm{mL}$ of $\mathrm{nMgO}$. The $\mathrm{nMgO}$ powder was dehydrated and sterilized in an oven at $200^{\circ} \mathrm{C}$ for at least one hour before each in vitro experiment. In order to obtain the prescribed concentrations of $0.2 \mathrm{mg} / \mathrm{mL}$ to $2.0 \mathrm{mg} / \mathrm{mL}$ of $\mathrm{nMgO}, 0.6-6.0 \mathrm{mg}$ of sterilized $\mathrm{nMgO}$ particles were weighed in the sterile $2 \mathrm{~mL}$ microcentrifuge tubes using an analytical balance (MS105D, Mettler Toledo) prior to the in vitro cultures with bacteria or yeasts. Three milliliters of the respective working stocks of diluted bacteria or yeasts with a concentration of $6 \times 10^{6}$ to $8 \times 10^{6}$ cells $/ \mathrm{mL}$ were transferred into the respective wells in the non-treated 12 -well culture plates. After the $3 \mathrm{~mL}$ of the respective bacterial or yeast suspension was transferred into the culture wells, $1 \mathrm{~mL}$ was placed into the respective microcentrifuge tubes to collect the previously weighed $\mathrm{nMgO}$ particles and transfer them into the respective wells of the 12-well plates. The culture plates were incubated for 24 hours in a shaker incubator at $37^{\circ} \mathrm{C}$ and $120 \mathrm{rpm}$. The shaking speed was reduced from the initial $220 \mathrm{rpm}$ for bacterial or yeast culture to prevent the microorganisms in one well spilling into neighboring wells. Experimental and control samples were all run in triplicates.

Quantify the concentration and viability of bacteria and yeasts after cultured with $0.2 \mathrm{mg} / \mathrm{mL}$ to $2.0 \mathrm{mg} / \mathrm{mL}$ of $n M g O$. After 24 hours of culture with $\mathrm{nMgO}$, the concentration and viability of the respective bacteria and yeasts were determined through plating and counting CFUs on their respective agar plates. Specifically, the broths containing the respective microorganism and the $\mathrm{nMgO}$ were collected into $15 \mathrm{~mL}$ conical tubes and vortexed. After that, $500 \mu \mathrm{L}$ was aliquoted into a $2 \mathrm{~mL}$ microcentrifuge tube and serially diluted in a Tris buffer. To quantify the CFUs, $100 \mu \mathrm{L}$ of the diluted or non-diluted suspension was spread onto the respective agar plates for that type of bacterium or yeast. The colonies on the agar plates were counted after they were incubated for $16-24$ hours in a $37^{\circ} \mathrm{C}$ incubator.

Evaluate the effects of $n \mathrm{MgO}$ on adhesion and morphology of the microorganisms of interest. In order to evaluate the possible changes in cell adhesion and morphology, the respective bacteria and yeasts were cultured on a glass square with $\mathrm{nMgO}$ in the range of $0-2.0 \mathrm{mg} / \mathrm{mL}$, using the same method as described above. Specifically, the borosilicate microscope cover glass (Fisherbrand, Fisher Scientific 12-542-B) were cut into $1 \mathrm{~cm} \times 1 \mathrm{~cm}$ squares, cleaned with acetone and ethanol sequentially under sonication for at least $30 \mathrm{~min}$ and sterilized in autoclave, and then placed into each culture well before adding the respective microorganisms and nMgO. The glass squares were used as a standard substrate for observing adhesion and morphology of each microorganism under scanning electron microscopy (SEM), because glass is a reproducible and widely-accepted reference for in vitro cultures involving mammalian cells and microorganisms. Each reference glass used here was thoroughly cleaned and sterilized to ensure that it does not induce random variables affecting the interactions of $\mathrm{nMgO}$ with the microorganisms.

After 24 hours of culture, the broths including the $\mathrm{nMgO}$ were collected, and the glass squares were rinsed three times with the Tris buffer. After the third wash, the respective microorganisms on the glass were fixed with $10 \%$ glutaraldehyde (Sigma Life Sciences, Sigma Aldrich) for one hour. After fixation, the samples were rinsed with a Tris buffer again three more times to wash away residual glutaraldehyde. These samples were dried in air at room temperature for at least 24 hours. The dried samples were sputter coated (108 Auto Sputter, Cressington) with Pt/Pd before SEM imaging. The SEM images were taken with backscattered electron detector, at an accelerating voltage of $10 \mathrm{kV}$ and working distance of $5 \mathrm{~mm}$. Bacteria were imaged at an original magnification of $5000 \mathrm{x}$ and the yeasts were imaged at the original magnifications of 500x and 5000x.

Analyze the broth $\mathrm{pH}$ and ion concentrations after culturing microorganisms with $\mathrm{nMgO}$. After 24 hours of culture with $\mathrm{nMgO}$, the collected broths were analyzed for $\mathrm{pH}$ using a calibrated $\mathrm{pH}$ meter (Symphony, VWR); and the concentrations of $\mathrm{Mg}^{2+}$ and $\mathrm{Ca}^{2+}$ ions in the collected broth were measured using inductively coupled plasma optical emission spectrometry (ICP-OES; Optima 8000, Perkin Elmer). The concentrations of calcium $\left(\mathrm{Ca}^{2+}\right)$ ions were measured in addition to the concentrations of $\mathrm{Mg}^{2+}$ ions because both $\mathrm{Mg}^{2+}$ and $\mathrm{Ca}^{2+}$ ions are relevant for cellular processes and nMgO was shown to affect the concentrations of both $\mathrm{Mg}^{2+}$ and $\mathrm{Ca}^{2+}$ ions in the culture media $^{18}$. The broths were first diluted with deionized water prior to the ICP-OES measurements of the ion concentrations. TSB was diluted to 1:20; and LBB and Sab broth were diluted to 1:50. Each sample was centrifuged to ensure that solid or debris from the culture was precluded from the ICP-OES measurements. The dilutions were performed one day before they were analyzed in the ICP-OES instrument.

Investigate the effects of $\mathrm{nMgO}$ against biofilms. Establishing a biofilm and exposing to $1.6 \mathrm{mg} / \mathrm{mL}$ of $n M g O$. S. epidermidis was selected as a model bacterium for investigating the effects of $\mathrm{nMgO}$ against biofilms because this gram-positive bacterium is one of the leading infectious agent for biofilm formation on medical devices and implants ${ }^{26,33}$. Bacteria culture and glass substrates were prepared using the same methods as described above. The protocol for establishing S. epidermidis biofilm was adapted from literature ${ }^{34}$. Briefly, the bacteria were cultured overnight, diluted at a factor of 1:100 with TSB; and $3 \mathrm{~mL}$ of diluted suspension was 
aliquoted onto a clean sterile glass substrate placed in each well of a 12-well non-treated culture plate. The culture plate was incubated at $37^{\circ} \mathrm{C}$ for 48 hours to form biofilms on the glass substrates in each well. Afterwards, the bacteria on glass substrates were taken out of some wells, and stained with crystal violet (CV; Fisher Scientific) and imaged under SEM to confirm that a biofilm had formed. After the S. epidermidis biofilm was established, $2 \mathrm{~mL}$ of broth was extracted and $2 \mathrm{~mL}$ of fresh TSB with or without $\mathrm{nMgO}$ was added into each well. For the experimental group with $\mathrm{nMgO}$, TSB with $1.6 \mathrm{mg} / \mathrm{mL} \mathrm{nMgO}$ was added. For the control group, only $2 \mathrm{~mL}$ of TSB was added without $\mathrm{nMgO}$. Afterwards, the culture plate was incubated at $37^{\circ} \mathrm{C}$ for another 24 hours.

Evaluating the biofilm disruption using crystal violet staining and SEM imaging. After the S. epidermidis biofilm was incubated with or without $\mathrm{nMgO}$ for 24 hours, each well was washed 3 times with Tris buffer to remove free $\mathrm{nMgO}$ and free bacteria, and then stained with $0.1 \% \mathrm{CV}$ in Tris buffer. After staining for 30 minutes, the culture wells were washed three times with deionized water to remove the unbound CV. After washing, all the samples on glass substrates were transferred to a new plate; the CV bound to bacteria was extracted and collected by submerging each sample in the $0.5 \mathrm{~mL}$ of $95 \%$ ethanol for 30 minutes, since only CV dissolves in ethanol. The extracted CV from each well was quantified by reading the absorbance at $570 \mathrm{~nm}$ using a spectrophotometer (Tecan, Infinite M2000 pro). To visualize the biofilm under SEM, the bacteria and biofilm on glass substrates were washed and fixed with $10 \%$ glutaraldehyde following the same procedures of sample preparation for SEM imaging, as described above.

Investigate the effects of increased $\mathrm{pH}$ and $\mathrm{Mg}^{2+}$ ion concentrations on bacteria. After the in vitro cultures of $\mathrm{nMgO}$ with the bacteria or yeasts for 24 hours, all the cultures showed increasing broth $\mathrm{pH}$ and $\mathrm{Mg}^{2+}$ ion concentrations due to dissociation of $\mathrm{nMgO}$. The effects of elevated $\mathrm{pH}$ or $\mathrm{Mg}^{2+}$ ion concentrations on the viability of bacteria was studied using S. epidermidis as a model microorganism. To determine the effects of increasing $\mathrm{pH}$ on bacterial viability, S. epidermidis were cultured in TSB with the initial $\mathrm{pH}$ intentionally adjusted to 7-10 using sodium hydroxide ( $\mathrm{NaOH}$, STREM Chemicals). At the end of 24 hours of culture, the viability of bacteria was quantified by plating and counting CFUs on agar plates; and the post-culture broth $\mathrm{pH}$ and ion concentrations were analyzed using the same methods as described above.

To determine the effects of increasing $\mathrm{Mg}^{2+}$ ions on bacterial viability, S. epidermidis was cultured in TSB doped with supplemental $\mathrm{Mg}^{2+}$ ions. For this purpose, the stock of $150 \mathrm{mM}$ of $\mathrm{Mg}^{2+}$ in broth were prepared by dissolving $1.525 \mathrm{~g}$ of magnesium chloride hexahydrate $\left(\mathrm{MgCl}_{2} \cdot 6 \mathrm{H}_{2} \mathrm{O}\right.$, Sigma Aldrich) in $50 \mathrm{~mL}$ of TSB. The $150 \mathrm{mM}$ stock was then diluted with the broth to obtain the TSB with supplemental $\mathrm{Mg}^{2+}$ dosage that ranged from 1 to $50 \mathrm{mM}$. The supplemental $\mathrm{Mg}^{2+}$ dosage reported here did not include the baseline $\mathrm{Mg}^{2+}$ ions already present in the TSB. That is, $0 \mathrm{mM}$ group means that no supplemental $\mathrm{Mg}^{2+}$ ion was added into the broth. At the end of 24 hours of culture, the viability of bacteria was quantified by plating and counting CFUs on agar plates; and the post-culture broth $\mathrm{pH}$ and ion concentrations were analyzed using the same methods as described above.

\section{Results}

Characterization of $\mathrm{nMgO}$. SEM and TEM images of $\mathrm{nMgO}$ confirmed its nanometer size and polyhedral morphology (Fig. 1A,B), which is in agreement with the information from the vendor. EDS analysis confirmed the elemental composition of the $\mathrm{MgO}$ nanoparticles containing magnesium $(\mathrm{Mg})$ and oxygen $(\mathrm{O})$, close to $1: 1$ atomic ratio (Fig. 1C). The expected crystalline phase of $\mathrm{nMgO}$ was confirmed with the standard peaks in the XRD pattern (Fig. 1D). The peaks for $\mathrm{Mg}(\mathrm{OH})_{2}$ were also present in the XRD spectrum, indicating the presence of $\mathrm{Mg}(\mathrm{OH})_{2}$ phase. The presence of $\mathrm{Mg}(\mathrm{OH})_{2}$ peaks in the XRD spectrum is expected, because MgO nanoparticles are hygroscopic and they can readily react with water in the atmosphere to form $\mathrm{Mg}(\mathrm{OH})_{2}$. The size distribution of $\mathrm{nMgO}$ particles was normal and narrow, with an average of $23 \pm 5 \mathrm{~nm}$, in agreement with the literature ${ }^{18}$. As listed in Table 1, the zeta potential and electrical mobility of $\mathrm{nMgO}$ in water were $32.31 \pm 4.1 \mathrm{mV}$ and $1.68 \pm 0.22$ $\left(\times 10^{-4} \mathrm{~cm}^{2} \mathrm{~V}^{-1} \mathrm{~s}^{-1}\right)$, similar to what were reported in literature ${ }^{35}$.

The concentration effects of $\mathrm{nMgO}$ on viability of major pathogenic bacteria and yeasts. The quantification of colony forming units (CFUs) in Fig. 2 showed that the viability of respective bacteria and yeasts were dependent on the $\mathrm{nMgO}$ concentrations. The critical MIC and MLC values of nMgO against each microorganism, are summarized in Table 2. The most potent concentration of $\mathrm{nMgO}$ (MPC) in the tested range of $0-2 \mathrm{mg} / \mathrm{mL}$ was $1.4 \mathrm{and} / \mathrm{or} 1.6 \mathrm{mg} / \mathrm{mL}$ for all the microorganism tested; and interestingly E. coli were completely killed at $1-2 \mathrm{mg} / \mathrm{mL}$ of $\mathrm{nMgO}$. The MPC values of $\mathrm{nMgO}$ could be valuable for potential clinical translations in the future where a wide spectrum of bacteria and yeasts are involved.

MBCs for gram-negative bacteria: E. coli and P. aeruginosa. MgO nanoparticles exhibited bactericidal effects against both $E$. coli and P. aeruginosa, as shown in Fig. 2A. However, the MBCs were different for the two gram-negative bacteria. Specifically, $1.0 \mathrm{mg} / \mathrm{mL}$ was the $\mathrm{MBC}_{99.99}$ of $\mathrm{nMgO}$ for E. coli and $1.2 \mathrm{mg} / \mathrm{mL}$ was the $\mathrm{MBC}_{90}$ of $\mathrm{nMgO}$ for $P$. aeruginosa. Interestingly, as the concentration of $\mathrm{nMgO}$ increased, $E$. coli changed quickly from proliferation at $0-0.7 \mathrm{mg} / \mathrm{mL}$ of $\mathrm{nMgO}$ to complete death at $1.0-2.0 \mathrm{mg} / \mathrm{mL}$ of $\mathrm{nMgO}$; that is, no viable E. coli was detected and no CFU was found on agar plates even when there was no dilution. In contrast, as the concentration of $\mathrm{nMgO}$ increased, $P$. aeruginosa gradually changed from proliferation at $0-0.7 \mathrm{mg} / \mathrm{mL}$ of $\mathrm{nMgO}$ to reduction in CFUs at $1.0-2.0 \mathrm{mg} / \mathrm{mL}$ of $\mathrm{nMgO}$. Specifically, $P$. aeruginosa was inhibited at $1.0 \mathrm{and} 1.2 \mathrm{mg} / \mathrm{mL}$ of $\mathrm{nMgO}$ and showed over $99.9 \%$ of death at $1.4-2.0 \mathrm{mg} / \mathrm{mL}$ of $\mathrm{nMgO}$.

MBCs for gram-positive bacteria: S. epidermidis, S. aureus and MRSA. MgO nanoparticles showed different inhibitory and bactericidal effects for the three gram-positive bacteria that are in the same genus of Staphylococcus, as shown in Fig. 2B. In general, as the concentration of $\mathrm{nMgO}$ increased, the CFU of S. epidermidis decreased. The 
A

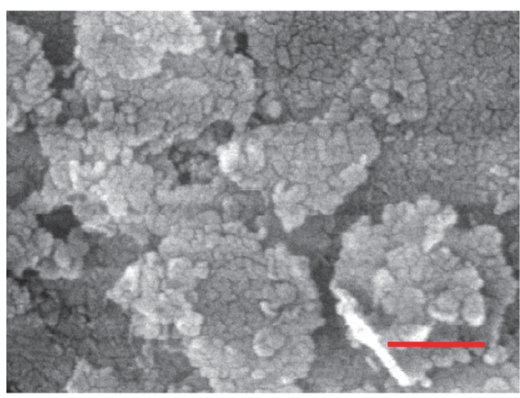

B

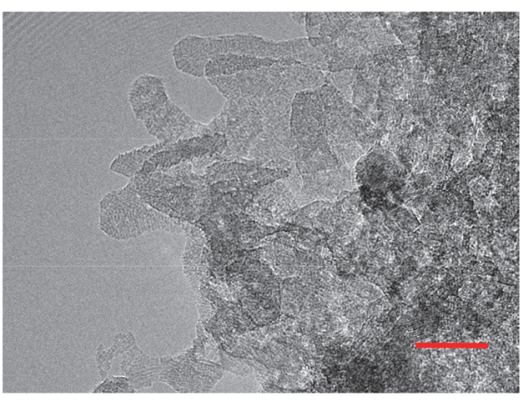

C

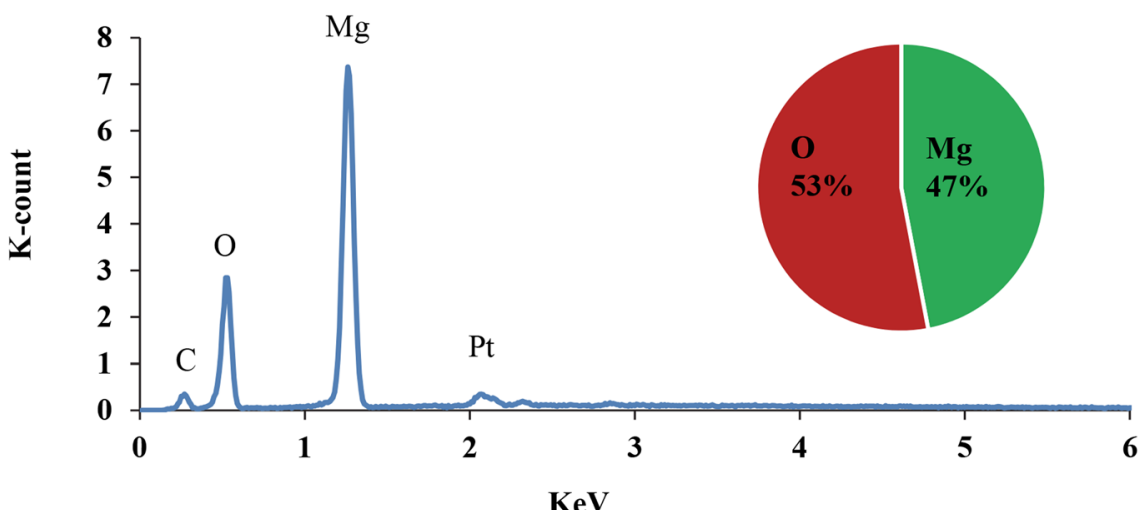

D

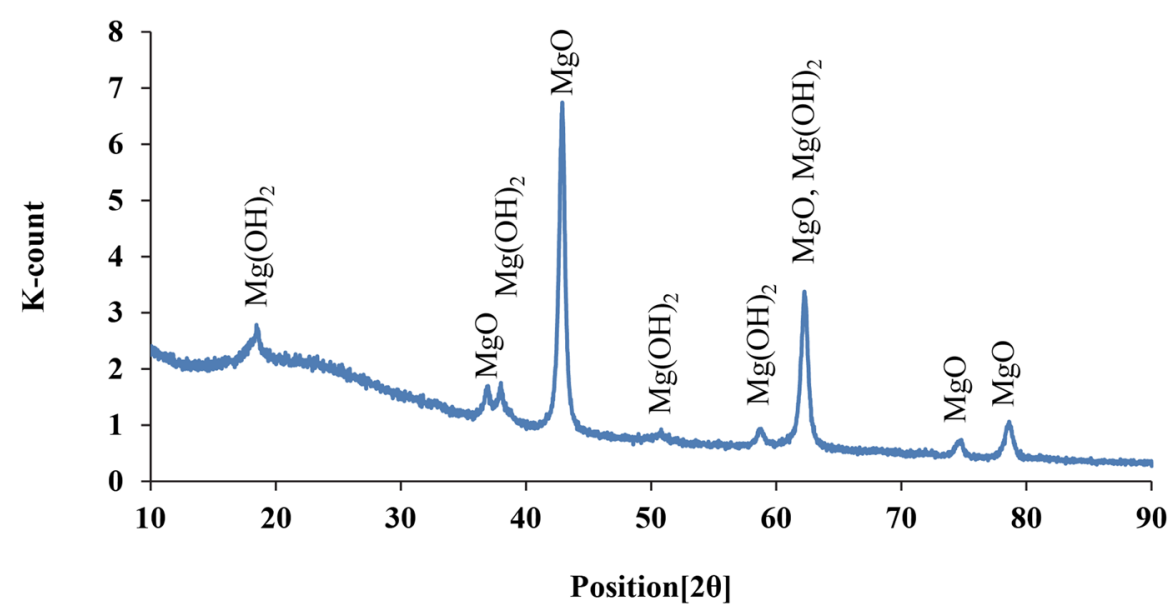

Figure 1. Characterization of microstructure, elemental composition, and phase of nMgO. (A) SEM image of $\mathrm{nMgO}$ at an original magnification of 250,000x. Scale bar: $200 \mathrm{~nm}$. (B) TEM image of nMgO, Scale bar: $20 \mathrm{~nm}$. (C) EDS analysis of nMgO. (D) XRD pattern of $\mathrm{nMgO}$.

\begin{tabular}{|l|l|l|}
\hline Sample & Zeta Potential $(\mathbf{m V})$ & Electrical mobility $\left(\times \mathbf{1 0}^{-4} \mathbf{c m}^{2} \mathbf{V}^{-1} \mathbf{s}^{-1}\right)$ \\
\hline $\mathrm{nMgO}$ & $32.31 \pm 4.1$ & $1.68 \pm 0.22$ \\
\hline
\end{tabular}

Table 1. Zeta potential and electrical mobility of $\mathrm{nMgO}$ in water.

growth of S. epidermidis was inhibited starting at $0.5 \mathrm{mg} / \mathrm{mL}$ of $\mathrm{nMgO}$. The $\mathrm{MBC}_{90}$ of $\mathrm{nMgO}$ for S. epidermidis was $0.7 \mathrm{mg} / \mathrm{mL}$. At $1.6 \mathrm{mg} / \mathrm{mL}$ of $\mathrm{nMgO}$, the average death rate of $S$. epidermidis was greater than $99.9 \%$ when compared with the initial seeding density of $(6-8) \times 10^{6}$ cells $/ \mathrm{mL}$. In contrast, higher concentrations of $\mathrm{nMgO}$ were required to inhibit the growth of $S$. aureus and MRSA, although the bacterial seeding density was similar. The growth of S. aureus was inhibited at $0.7 \mathrm{mg} / \mathrm{mL}$ of $\mathrm{nMgO}$, and the $\mathrm{MBC}_{90}$ of $\mathrm{nMgO}$ for $S$. aureus was also at $0.7 \mathrm{mg} / \mathrm{mL}$. At $1.4 \mathrm{mg} / \mathrm{mL}$ of $\mathrm{nMgO}$, the CFU of $S$. aureus reached the lowest and showed a death rate of greater than $99.99 \%$; that is, less than $0.01 \%$ of bacteria was viable. Although not statistically significant, at higher concentrations of $\mathrm{nMgO}$, such as 1.6 and $2.0 \mathrm{mg} / \mathrm{mL}$, the average number of viable $S$. aureus was higher than that at $1.4 \mathrm{mg} / \mathrm{mL}$ of $\mathrm{nMgO}$; and $S$. aureus still exhibited at least $99 \%$ of death rate. Similar trend was observed in $P$. aeruginosa, the average CFU was higher at $2.0 \mathrm{mg} / \mathrm{mL}$ of $\mathrm{nMgO}$ when compared with that at $1.4 \mathrm{mg} / \mathrm{mL}$ of $\mathrm{nMgO}$ (Fig. $2 \mathrm{~A}$ ). 

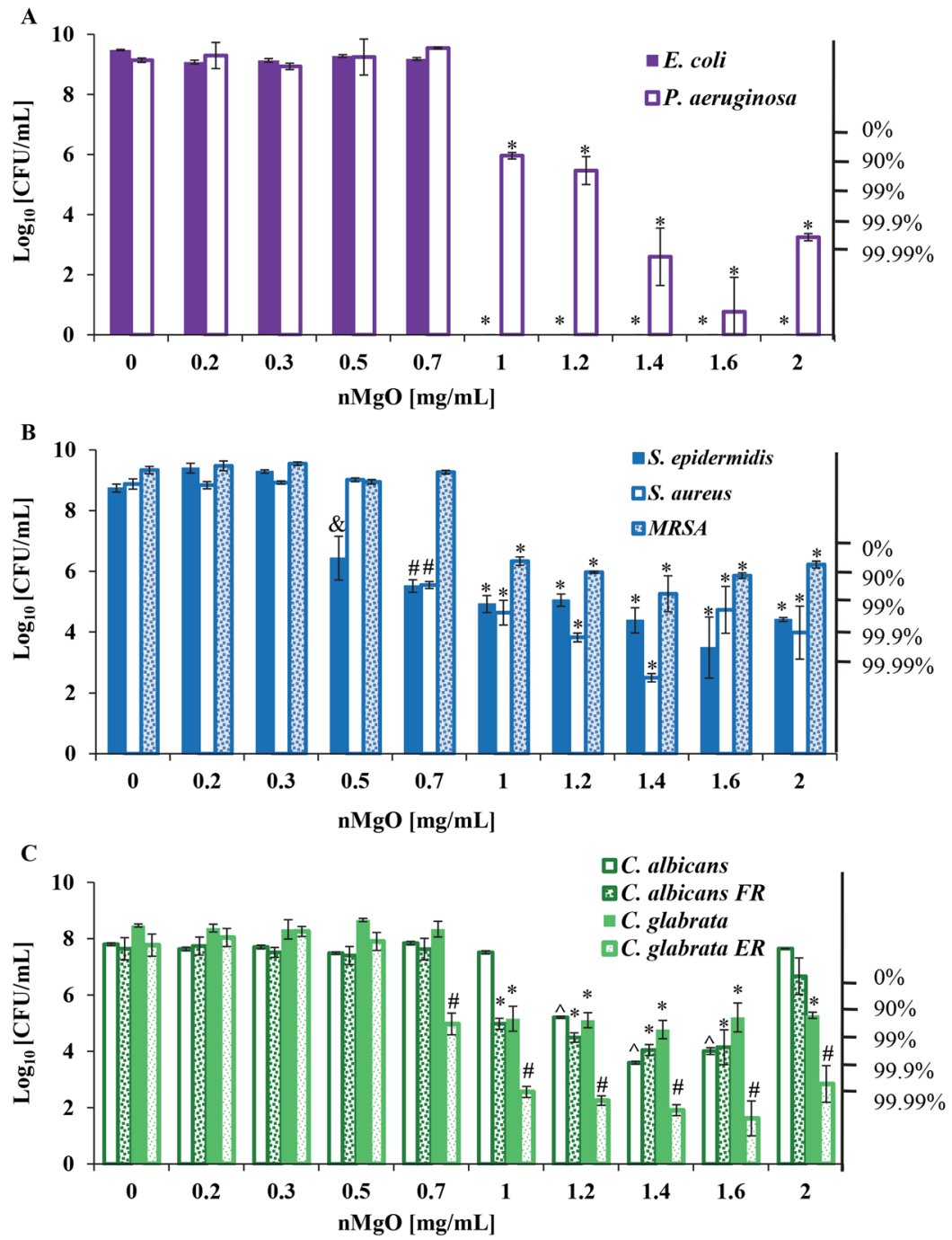

Figure 2. Colony forming units (CFU) quantified for the viable bacteria and yeasts after 24 hours of culture with $0-2.0 \mathrm{mg} / \mathrm{mL}$ of nMgO. (A) CFUs of gram-negative bacteria, including E. coli and P. aeruginosa. (B) CFUs of gram-positive bacteria, including S. epidermidis, S. aureus, and methicillin-resistant Staphylococcus aureus (MRSA). (C) CFUs of drug-sensitive and drug-resistant fungi, including C. albicans, C. albicans FR, C. glabrata, and C. glabrata ER. Data are mean \pm standard deviation $(\mathrm{N}=9) . \mathrm{FR}=$ Fluconazole resistant and $\mathrm{ER}=$ Echinocandin resistant. ${ }^{*} p \leq 0.05$ : significantly lower than the groups at $0-0.7 \mathrm{mg} / \mathrm{mL}$ of $\mathrm{nMgO}$ for the respective bacterium or yeast. $\wedge p \leq 0.05$ : significantly lower than the groups at $0-1 \mathrm{mg} / \mathrm{mL}$ of $\mathrm{nMgO}$ for the respective microorganism. ${ }^{\#} p \leq 0.05$ : significantly lower than the groups at $0-0.5 \mathrm{mg} / \mathrm{mL}$ of $\mathrm{nMgO}$ for the respective microorganism. ${ }^{\circledR} p \leq 0.05$ : significantly lower than the groups at $0-0.3 \mathrm{mg} / \mathrm{mL}$ of $\mathrm{nMgO}$ for the respective microorganism.

MRSA is a methicillin resistant $S$. aureus strain, which was known to be extremely difficult to treat as it can easily become resistant to new antibiotic drugs. Much higher concentrations of $n \mathrm{MgO}$ were needed to inhibit the growth of MRSA. Specifically, MRSA growth was inhibited at $1.0 \mathrm{mg} / \mathrm{mL}$ of $\mathrm{nMgO}$, which is a much higher MIC than that for S. epidermidis and S. aureus (Fig. 2B). The $\mathrm{MBC}_{90}$ of $\mathrm{nMgO}$ for MRSA was $1.4 \mathrm{mg} / \mathrm{mL}$, much higher than that for S. epidermidis and S. aureus.

MFCs for yeasts: C. albicans, C. albicans FR, C. glabrata, and C. glabrata ER. Yeasts are often found in the biofilms on catheters and other medical devices and contribute to the infections. C. albicans and C. glabrata are two different yeast species in the same genus, and have different characteristics such as the virulence factors and morphology. It was not surprising that these yeasts behaved differently when they were exposed to $\mathrm{nMgO}$, as shown in Fig. 2C. In general, between the two drug-sensitive and drug-resistant C. albicans strains, C. albicans FR appeared to be more sensitive to $\mathrm{nMgO}$ than C. albicans at certain concentrations of $\mathrm{nMgO}$, such as 1.0 and $1.2 \mathrm{mg} / \mathrm{mL}$ of $\mathrm{nMgO}$. At $1.0 \mathrm{mg} / \mathrm{mL}$ of nMgO, C. albicans FR exhibited at least $90 \%$ of death rate, while the growth of C. albicans was not inhibited at the same concentration (Fig. 2C). At the concentrations of $1.2 \mathrm{mg} / \mathrm{mL}$ of nMgO, over $90 \%$ of C. albicans and over $99 \%$ of C. albicans $F R$ were dead. At 1.4 and $1.6 \mathrm{mg} / \mathrm{mL}$ of $\mathrm{nMgO}$, the average death rate of C. albicans and C. albicans FR were $99 \%$ or greater. However, at $2.0 \mathrm{mg} / \mathrm{mL}$ of $\mathrm{nMgO}$, both C. albicans and 


\begin{tabular}{|c|c|c|c|c|c|c|c|}
\hline \multirow{2}{*}{\multicolumn{2}{|c|}{ Microorganisms }} & \multicolumn{6}{|c|}{ MIC, MLC and MPC of $\mathrm{nMgO}[\mathrm{mg} / \mathrm{mL}]$} \\
\hline & & \multirow{2}{*}{\begin{tabular}{|l|} 
MIC \\
1.0 \\
\end{tabular}} & \multirow{2}{*}{$\begin{array}{l}\text { MLC }_{90} \\
1.0\end{array}$} & \multirow{2}{*}{$\begin{array}{l}\text { MLC }_{99} \\
1.0\end{array}$} & \multirow{2}{*}{\begin{tabular}{|l|} 
MLC $_{99.9}$ \\
1.0
\end{tabular}} & \multirow{2}{*}{\begin{tabular}{|l|} 
MLC $_{99.99}$ \\
1.0 \\
\end{tabular}} & \multirow{2}{*}{$\begin{array}{l}\text { MPC } \\
1.0-2\end{array}$} \\
\hline \multirow{2}{*}{ Gram-negative bacteria } & E. coli & & & & & & \\
\hline & P. aeruginosa & 1.0 & 1.2 & 1.4 & 1.4 & 1.6 & 1.6 \\
\hline \multirow{3}{*}{ Gram-positive bacteria } & S. epidermidis & 0.5 & 0.7 & 1.0 & 1.6 & N/A* & 1.6 \\
\hline & S. aureus & 0.7 & 0.7 & 1.0 & 1.2 & 1.4 & 1.4 \\
\hline & MRSA & 1.0 & 1.4 & N/A & N/A & N/A* & 1.4 \\
\hline \multirow{4}{*}{ Drug-sensitive and resistant yeasts } & C. albicans & 1.2 & 1.2 & 1.4 & N/A & N/A* & 1.4 \\
\hline & C. albicans FR & 1.0 & 1.0 & 1.4 & N/A & N/A* & $1.4 ; 1.6$ \\
\hline & C. glabrata & 1.0 & 1.0 & 1.4 & N/A & N/A* & 1.4 \\
\hline & C. glabrata ER & 0.7 & 0.7 & 1.0 & 1.0 & 1.2 & \begin{tabular}{|l}
$1.4 ; 1.6$ \\
\end{tabular} \\
\hline
\end{tabular}

Table 2. Summary of MIC and MLC values of nMgO against all the pathogenic bacteria and fungi tested. *Indicates the species that never reached $99.99 \%$ death rate in the tested range of $0-2 \mathrm{mg} / \mathrm{mL}$ of $\mathrm{nMgO}$. MPC is the most potent concentration of $\mathrm{nMgO}$ in the tested range of $0-2 \mathrm{mg} / \mathrm{mL}$ against each microorganism. MLC is the minimal lethal concentration that refers to MBC for bacteria and MFC for yeasts.

C. albicans FR showed no reduction in CFUs when compared with their initial seeding density. The greater CFUs of C. albicans and C. albicans $F R$ at $2.0 \mathrm{mg} / \mathrm{mL}$ of $\mathrm{nMgO}$ suggested a possible paradoxical effect of $\mathrm{nMgO}$ on both strains of C. albicans (Fig. 2C).

Similarly, $\mathrm{MgO}$ nanoparticles showed higher fungicidal potency against drug-resistant C. glabrata ER than drug-sensitive C. glabrata, as shown in Fig. 2C. The MFC of nMgO was $0.7 \mathrm{mg} / \mathrm{mL}$ for C. glabrata ER, and $1.0 \mathrm{mg} /$ $\mathrm{mL}$ for C. glabrata. At $1.0 \mathrm{mg} / \mathrm{mL}$ of $\mathrm{nMgO}$, C. glabrata ER showed over $99.9 \%$ of death rate, while C. glabrata showed over $90 \%$ of death rate. At $1.2-1.6 \mathrm{mg} / \mathrm{mL}$ of nMgO, C. glabrata ER showed over $99.99 \%$ of death rate, while C. glabrata showed over $90 \%$ of death rate. For C. glabrata, the percentages of fungal death stayed at $90-99 \%$ at $1.2-2 \mathrm{mg} / \mathrm{mL}$ of $\mathrm{MgO}$.

Analyses of post-culture broths. The pH of post-culture broths. Generally, when the nMgO concentrations increased, the $\mathrm{pH}$ of all the broths showed an increasing trend for all of the cultures after 24 hours, as shown in Fig. 3A. For gram-negative bacteria, from $0.2-0.7 \mathrm{mg} / \mathrm{mL}$ of $\mathrm{nMgO}$, the $\mathrm{pH}$ increased to 8-9. At the concentrations where MICs or $\mathrm{MBCs}_{90}$ were observed for E. coli and P. aeruginosa, the $\mathrm{pH}$ increased to above 9 . For gram-positive bacteria, the $\mathrm{pH}$ started to increase with the addition of $\mathrm{nMgO}$ starting at $0.2 \mathrm{mg} / \mathrm{mL}$, when compared with the control group of $0 \mathrm{mg} / \mathrm{mL} \mathrm{nMgO}$. However, when gram-positive bacteria multiplied in the absence of $\mathrm{nMgO}$ (i.e., the group of $0 \mathrm{mg} / \mathrm{mL} \mathrm{nMgO}$ ), they reduced the broth $\mathrm{pH}$ to be more acidic than the broth control (i.e., TSB). When compared with the broth control, the $\mathrm{pH}$ increased significantly at $0.5 \mathrm{mg} / \mathrm{mL}, 0.7 \mathrm{mg} / \mathrm{mL}$ and $1.0 \mathrm{mg} / \mathrm{mL}$ of $\mathrm{nMgO}$ cultured with S. epidermidis, S. aureus, and MRSA, respectively. Interestingly, the growths of S. epidermidis, S. aureus, and MRSA were also inhibited at $0.5 \mathrm{mg} / \mathrm{mL}, 0.7 \mathrm{mg} / \mathrm{mL}$, and $1.0 \mathrm{mg} / \mathrm{mL}$, respectively.

The $\mathrm{pH}$ of the post-culture Sab broths for different yeast strains showed similar trends as that of the gram-positive bacteria. Specifically, the $\mathrm{pH}$ of the yeast cultures started to increase with the addition of $\mathrm{nMgO}$ starting at $0.2 \mathrm{mg} / \mathrm{mL}$, when compared with the control group of $0 \mathrm{mg} / \mathrm{mL} \mathrm{nMgO}$. However, when yeasts were cultured in the absence of $\mathrm{nMgO}$ (i.e., the group of $0 \mathrm{mg} / \mathrm{mL} \mathrm{nMgO}$ ), they reduced the broth $\mathrm{pH}$ from around 5 to less than 4 . The Sab broth controls showed $\mathrm{pH}$ values around 5, more acidic than TSB or LBB. The $\mathrm{pH}$ increased to above 9 at $1.0-2.0 \mathrm{mg} / \mathrm{mL}$ of $\mathrm{nMgO}$ for almost all the yeasts strains, except for C. albicans; the broth of C. albicans cultured with $2.0 \mathrm{mg} / \mathrm{mL}$ was around 7.1 . Interestingly, at $2.0 \mathrm{mg} / \mathrm{mL}$ of $\mathrm{nMgO}$, the growth of C. albicans also increased (Fig. 3A).

Ion concentrations in post-culture broths. Generally, when the $\mathrm{nMgO}$ concentrations increased, $\mathrm{Mg}^{2+}$ ion concentrations in all the post-culture broths increased after 24 hours of culture, as shown in Fig. 3B. At $0 \mathrm{mg} / \mathrm{mL}$ $\mathrm{nMgO}$ (i.e., without adding $\mathrm{nMgO}$ ), the $\mathrm{Mg}^{2+}$ ion concentrations in the post-culture broths for all the microorganisms tested were essentially the same as the broth only controls without cells. At $0.2 \mathrm{mg} / \mathrm{mL}$ and above, the $\mathrm{Mg}^{2+}$ ion concentrations in the post-culture broths were greater than the broth only controls and the $0 \mathrm{mg} / \mathrm{mL}$ $\mathrm{nMgO}$ groups; moreover, the increasing trends of $\mathrm{Mg}^{2+}$ ion concentrations in the cultures with increasing concentrations of $\mathrm{nMgO}$ were nearly linear for all the cultures with different microorganisms.

In contrast, the trends for $\mathrm{Ca}^{2+}$ ion concentrations in the post-culture broths varied among the different bacterial and yeast strains, as shown in Fig. 3C. In general, $\mathrm{Ca}^{2+}$ ion concentrations for the groups at the $2.0 \mathrm{mg} / \mathrm{mL}$ of $\mathrm{nMgO}$ were higher than the groups at lower $\mathrm{nMgO}$ concentrations for the respective microorganisms tested. For E. coli, $\mathrm{Ca}^{2+}$ ion concentrations showed no significant difference between the broth control and $0 \mathrm{mg} / \mathrm{mL} \mathrm{nMgO}$ control group after 24 hours of culture; moreover, $\mathrm{Ca}^{2+}$ ion concentrations slightly decreased at $0.2 \mathrm{mg} / \mathrm{mL} \mathrm{nMgO}$ group and then increased at 0.3 to $2.0 \mathrm{mg} / \mathrm{mL} \mathrm{nMgO}$ groups, when compared with the controls. For P. aeruginosa, the $\mathrm{Ca}^{2+}$ ion concentrations slightly decreased for the $\mathrm{nMgO}$ groups of $0-0.5 \mathrm{mg} / \mathrm{mL}$ as compared with the broth control group; however, the $\mathrm{Ca}^{2+}$ ion concentrations gradually increased for the groups of $0.7-2.0 \mathrm{mg} / \mathrm{mL}$ of $\mathrm{nMgO}$. For gram-positive bacteria of S. epidermidis, S. aureus, and MRSA, in general, the $\mathrm{Ca}^{2+}$ ion concentrations showed a slight gradual trend of increase with increasing $\mathrm{nMgO}$ concentrations with a few exceptions. For S. epidermidis, the $\mathrm{Ca}^{2+}$ ion concentrations showed a slight drop at $0.3 \mathrm{mg} / \mathrm{mL} \mathrm{nMgO}$ along the general increasing trend. The $\mathrm{Ca}^{2+}$ ion concentrations showed no significant difference between the broth control and $0 \mathrm{mg} / \mathrm{mL}$ 
A
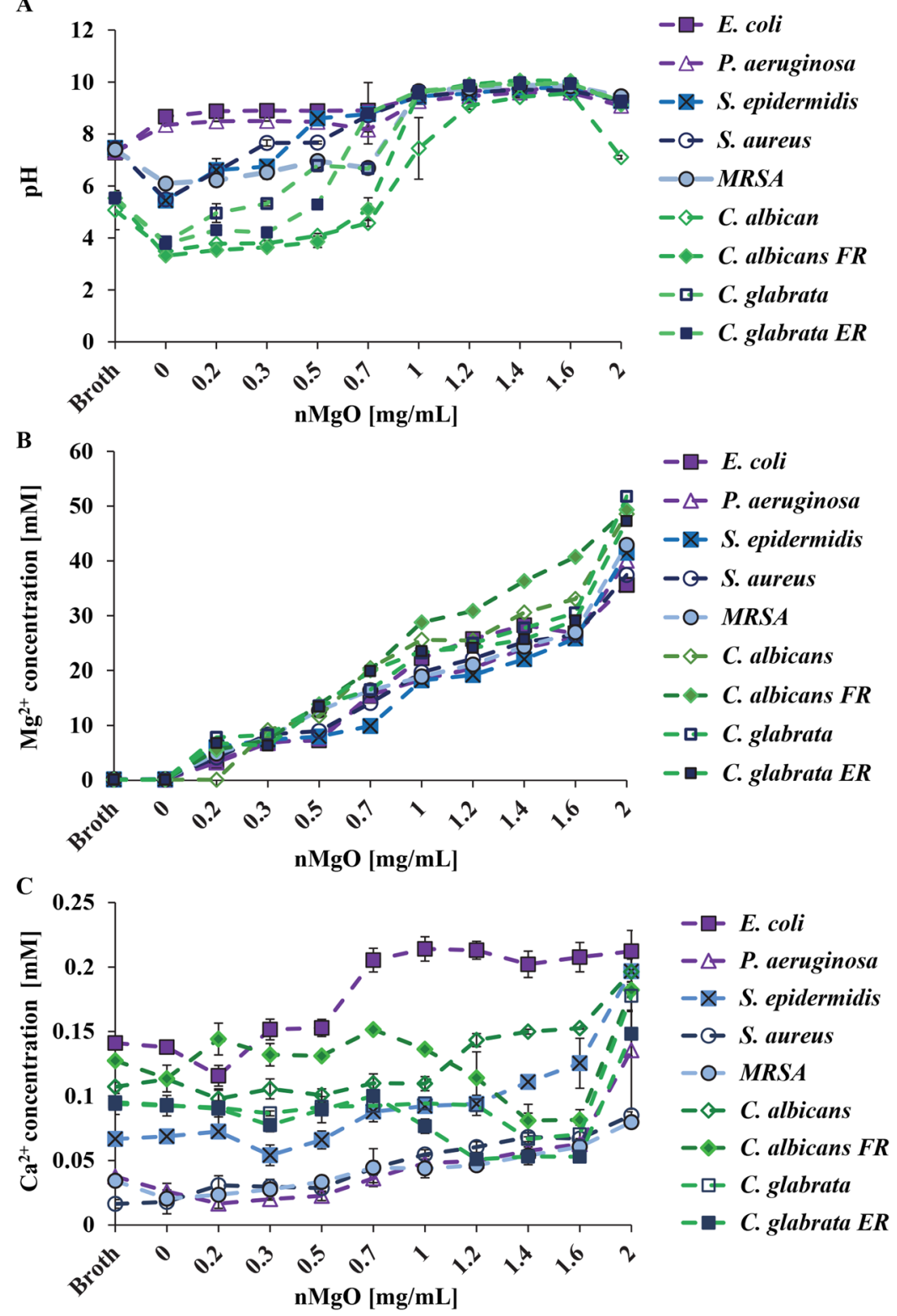

Figure 3. Broth analysis after bacteria and yeasts were cultured with $0-2.0 \mathrm{mg} / \mathrm{mL}$ of $\mathrm{nMgO}$ for 24 hours. (A) The $\mathrm{pH}$ of the post-culture broths. (B) The concentrations of $\mathrm{Mg}^{2+}$ ions in post-culture broths. (C) The concentrations of $\mathrm{Ca}^{2+}$ ions in post-culture broths. Expanded views of $\mathrm{Ca}^{2+}$ ion concentrations are available in Supplementary Materials (Figures S1, S2, S4).

$\mathrm{nMgO}$ control group for S. epidermidis and S. aureus, but the MRSA control group (i.e. $0 \mathrm{mg} / \mathrm{mL} \mathrm{nMgO}$ group) reduced the $\mathrm{Ca}^{2+}$ ion concentration when compared with its broth control.

For the four yeasts tested, the trends of $\mathrm{Ca}^{2+}$ ion concentrations varied for different yeast types (Fig. 3C). Specifically, the $\mathrm{Ca}^{2+}$ ion concentrations for C. albicans were lower for the groups at $0.2-1.0 \mathrm{mg} / \mathrm{mL}$ of $\mathrm{nMgO}$ than the broth only control, and then increased at $1.2-2 \mathrm{mg} / \mathrm{mL}$ of $\mathrm{nMgO}$. In contrast, the $\mathrm{Ca}^{2+}$ ion concentrations in the post-culture broths with C. albicans FR fluctuated and showed a shape of spoon. Specifically, the $\mathrm{Ca}^{2+}$ concentrations observed at $0.2,0.7$ and $2.0 \mathrm{mg} / \mathrm{mL}$ of $\mathrm{nMgO}$ were higher than the broth control and the other groups; and the $\mathrm{Ca}^{2+}$ ion concentrations for the groups of $1.2-1.6 \mathrm{mg} / \mathrm{mL}$ of nMgO were lower. For the two C. glabrata strains, $\mathrm{Ca}^{2+}$ ion concentrations showed similar trends with a spoon shape; at $1.0-2.0 \mathrm{mg} / \mathrm{mL}$ of $\mathrm{nMgO}$, the $\mathrm{Ca}^{2+}$ ion concentrations in the cultures with C. glabrata ER were less than that for C. glabrata.

The correlation between the concentrations of soluble $\mathrm{Ca}^{2+}$ ions in the broth and CFUs for gram-negative bacteria, gram-positive bacteria, and yeasts are presented clearly in the Supplementary Materials (Figures S1, S2 and S4).

Adhesion and morphology of the bacteria and yeasts after exposure to nMgO. As shown in the SEM images in Figs 4-9, the nMgO did affect the adhesion and morphology of the bacteria and yeasts of interest, 


\section{E. coli}

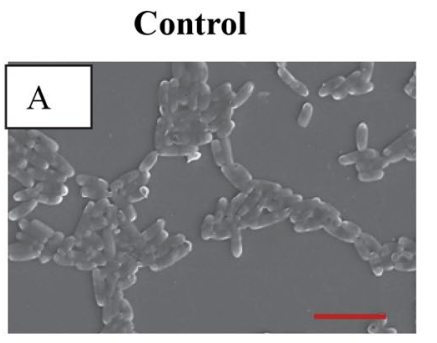

$0.7 \mathrm{nMgO}$

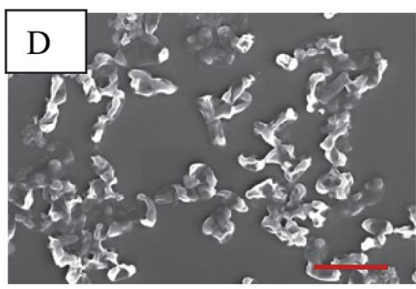

\section{P. aeruginosa}

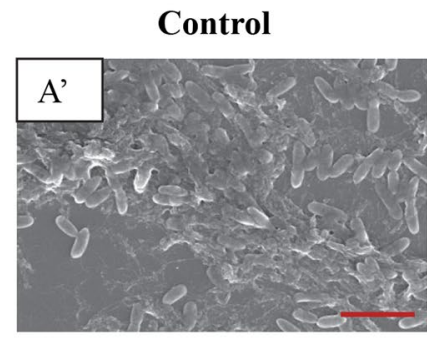

$0.7 \mathrm{nMgO}$

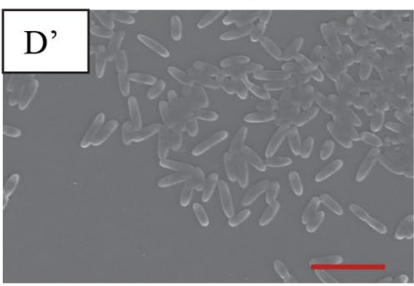

$0.2 \mathrm{nMgO}$

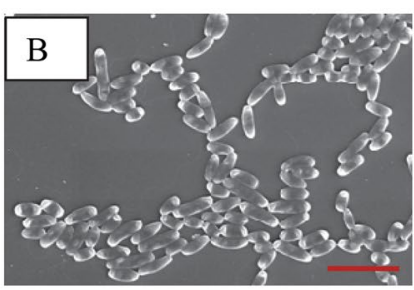

$1.0 \mathrm{nMgO}$

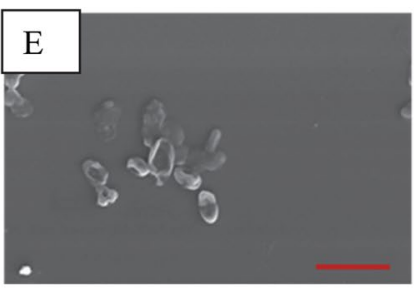

$0.2 \mathrm{nMgO}$

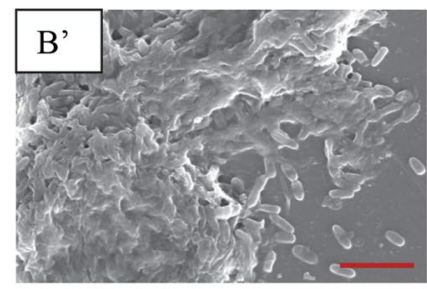

$1.0 \mathrm{nMgO}$

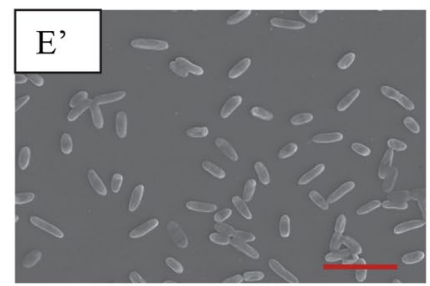

$0.5 \mathrm{nMgO}$

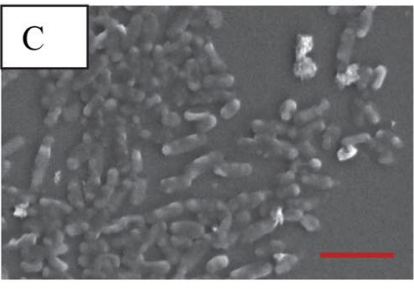

$1.2 \mathrm{nMgO}$

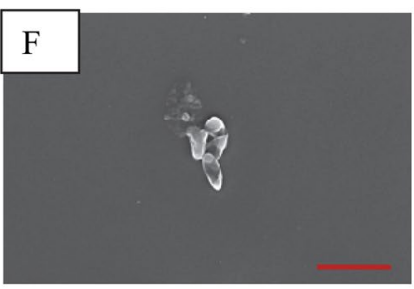

Figure 4. SEM images of gram-negative bacteria, including E. coli and P. aeruginosa, showing their morphology after they were cultured with $0-2.0 \mathrm{mg} / \mathrm{mL}$ of $\mathrm{nMgO}$ for 24 hours. Scale bar: $5 \mu \mathrm{m}$ with an original magnification of 5000x. (A) to (F) is E. coli, and (A)' to (F)' is P. aeruginosa. The bacteria showed similar morphology at $1.2-2.0 \mathrm{mg} / \mathrm{mL}$ of $\mathrm{nMgO}$, and thus only one image at $1.2 \mathrm{mg} / \mathrm{mL}$ of $\mathrm{nMgO}$ for each bacterial type is shown as a representative for those at the higher $\mathrm{nMgO}$ concentrations.

depending on the concentrations of $\mathrm{nMgO}$. In general, when the concentrations of $\mathrm{nMgO}$ increased, the adhesion densities of gram-negative bacteria, gram-positive bacteria, and yeasts decreased. Based on the SEM images, $\mathrm{nMgO}$ showed different effects on the morphology of each microorganism.

The $\mathrm{nMgO}$ particles disrupted the morphology of E. coli more obviously than the other bacteria (Figs 4 and 5). At $0.7 \mathrm{mg} / \mathrm{mL}$ of $\mathrm{nMgO}$ and higher, the shape of $E$. coli was distorted with observable damages in its cell wall and cell membrane (Fig. 4D-F), in contrast to its typical rod shape as seen in the control group (Fig. 4A). The number of $E$. coli attached onto the substrate decreased significantly at the $\mathrm{nMgO}$ concentrations of $1.0-2.0 \mathrm{mg} / \mathrm{mL}$; the concentration of $1.0 \mathrm{mg} / \mathrm{mL}$ was the $\mathrm{MBC}$ of $\mathrm{nMgO}$ for $E$. coli. When compared with $E$. coli, no obvious membrane damage was observed for P. aeruginosa, although it is also a gram-negative bacterium. Nevertheless, the numbers of attached $P$. aeruginosa decreased when the concentrations of nMgO increased (Fig. 4A'-F'). For the groups at $0 \mathrm{mg} / \mathrm{mL}$ (i.e., bacterial control) and $0.2 \mathrm{mg} / \mathrm{mL}$ of $\mathrm{nMgO}$, P. aeruginosa aggregated with an appearance of a biofilm (Fig. $4 A^{\prime}, B^{\prime}$ ). At the higher concentrations of $\mathrm{nMgO}$, i.e., $1.0-2.0 \mathrm{mg} / \mathrm{mL}$, not only the number of attached $P$. aeruginosa significantly reduced, but also the attached bacteria were scattered rather than in the form of clusters as seem in a biofilm. 


\section{S. epidermidis}

Control

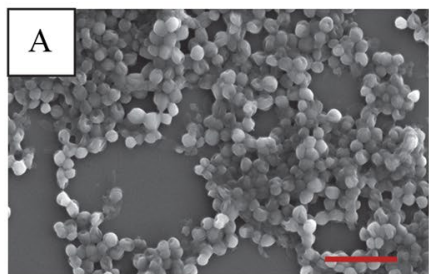

S. aureus

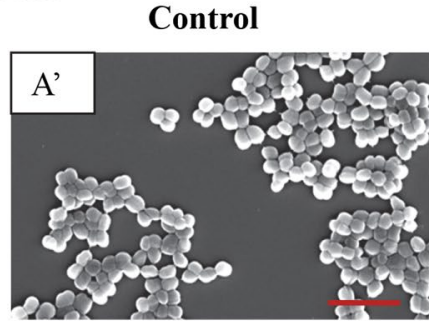

0.7 nMgO

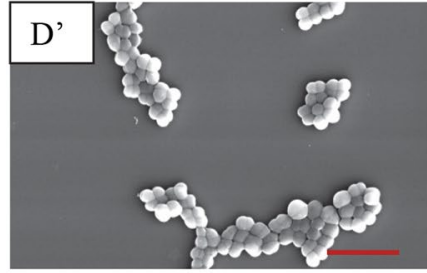

MRSA

Control

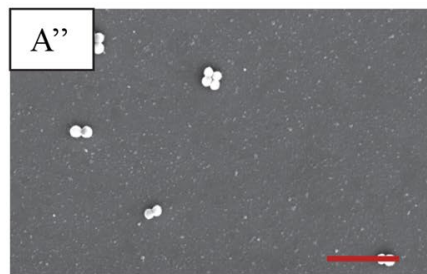

$0.2 \mathrm{nMgO}$

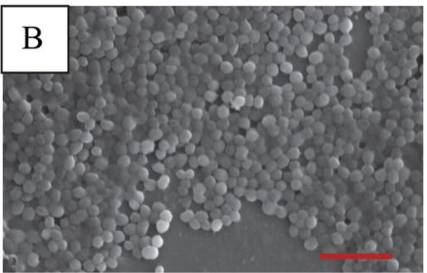

0.2 nMgO

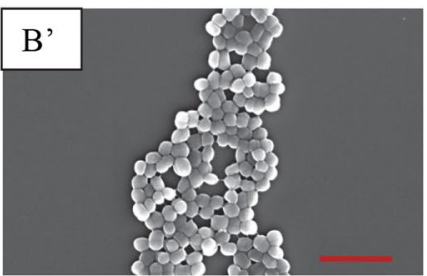

$1.0 \mathrm{nMgO}$

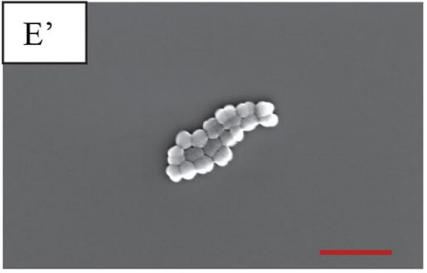

$0.2 \mathrm{nMgO}$

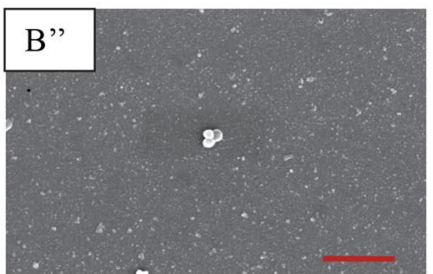

0.5 nMgO



0.5 nMgO

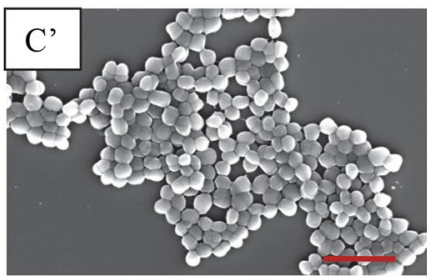

$1.2 \mathrm{nMgO}$

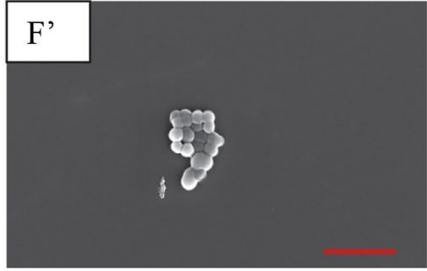

Figure 5. SEM images of gram-positive bacteria, including S. epidermidis, S. aureus and MRSA, showing their morphology after they were cultured with $0-2.0 \mathrm{mg} / \mathrm{mL}$ of $\mathrm{nMgO}$ for 24 hours. Scale bar: $5 \mu \mathrm{m}$ with an original magnification of 5000x. (A to C) is S. epidermidis; the bacteria at higher concentrations of nMgO were very similar to that at $0.5 \mathrm{mg} / \mathrm{mL}$ of $\mathrm{nMgO}$, and only one image is shown as a representative for those at the higher $\mathrm{nMgO}$ concentrations. ( $\mathbf{A}^{\prime}$ to $\mathbf{F}^{\prime}$ ) is $S$. aureus; the bacteria at $1.2-2.0 \mathrm{mg} / \mathrm{mL}$ of $\mathrm{nMgO}$ were similar, and thus only one image at $1.2 \mathrm{mg} / \mathrm{mL} \mathrm{nMgO}$ is shown as a representative for those at the higher $\mathrm{nMgO}$ concentrations. (A"C") is MRSA; very few adhered MRSA were found with increasing concentrations of nMgO (none when $\mathrm{nMgO}$ concentration $>0.5 \mathrm{mg} / \mathrm{mL}$ ), and thus images are not shown for the higher $\mathrm{nMgO}$ concentrations.

For the gram-positive bacteria, no apparent damage was observed on cell wall or cell membrane when cultured with $\mathrm{nMgO}$, and the cocci (or spherical) shape remained similar to the control group without $\mathrm{nMgO}$ (Fig. 5). At $0 \mathrm{mg} / \mathrm{mL}$ and $0.2 \mathrm{mg} / \mathrm{mL}$ of $\mathrm{nMgO}$, S. epidermidis aggregated and showed a morphology similar to a biofilm (Fig. 5A,B). At $0.5 \mathrm{mg} / \mathrm{mL}$ of $\mathrm{nMgO}$ and above, the number of $S$. epidermidis attached onto the substrate surface decreased significantly (Fig. 5C). As confirmed in Fig. 2, the growth of S. epidermis was inhibited at $0.5 \mathrm{mg} / \mathrm{mL}$ of $\mathrm{nMgO}$ with the CFU lower than the control. For the groups at the $\mathrm{nMgO}$ concentrations higher than $0.5 \mathrm{mg} / \mathrm{mL}$, the SEM images for S. epidermidis and MRSA were not shown because they were very similar to the groups at $0.5 \mathrm{mg} / \mathrm{mL}$ of $\mathrm{nMgO}$, i.e., only a few or no bacteria were found. S. aureus formed clusters when attached onto the substrate surface; the clusters were smaller in size with less number of bacteria attached on the surface at the higher $\mathrm{nMgO}$ concentrations (Fig. 5A'-F'). A few MRSA attached onto the substrate surface, even in the control group without $\mathrm{nMgO}$ (Fig. 5A"). Even fewer attached MRSA were found at 0.2 and $0.5 \mathrm{mg} / \mathrm{mL}$ of $\mathrm{nMgO}$ (Fig. 5B",C"), and none was found for the groups with greater than $0.5 \mathrm{mg} / \mathrm{mL} \mathrm{nMgO}$. Furthermore, the attached MRSA formed very small clusters with only two to six bacteria. 


\section{C. albicans}
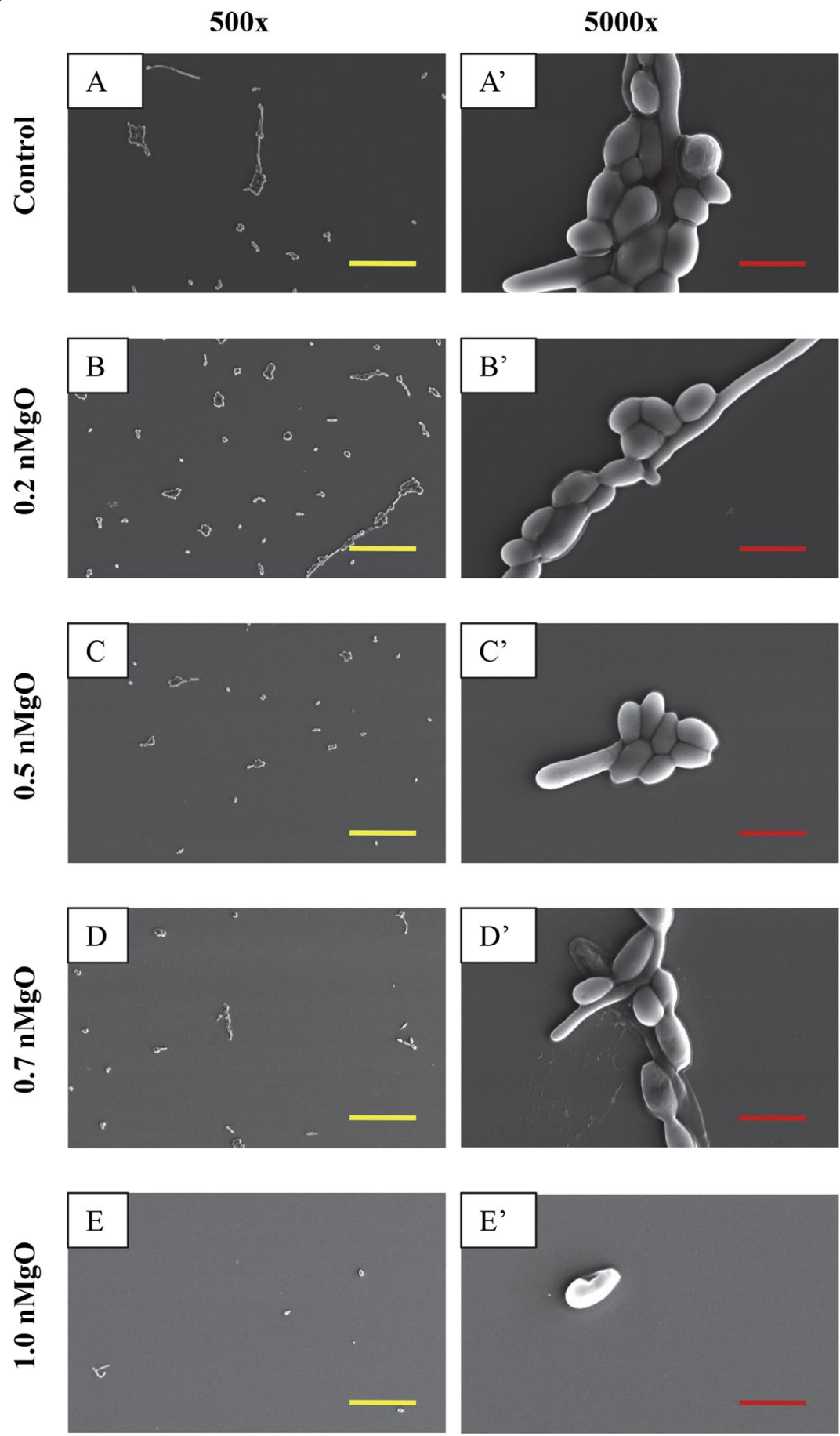

Figure 6. SEM images of C. albicans, showing its morphology after 24 hours of culture with $0-2.0 \mathrm{mg} / \mathrm{mL}$ of $\mathrm{nMgO}$. (A to E) Images at an original magnification of 500x with a scale bar of $50 \mu \mathrm{m}$. (A' to E') Images at an original magnification of $5000 \mathrm{x}$ with a scale bar of $5 \mu \mathrm{m}$. At $1.0-2.0 \mathrm{mg} / \mathrm{mL}$ of $\mathrm{nMgO}$, the cell morphology was similar, and thus only one image at each magnification at $1.0 \mathrm{mg} / \mathrm{mL}$ of $\mathrm{nMgO}$ is shown as a representative for those at the higher $\mathrm{nggO}$ concentrations.

Yeasts as eukaryotes are typically larger than bacteria, and thus their SEM images were taken at both low and high magnifications (Figs 6-9). The SEM images at the original magnification of 500x were to show a representative overview of the yeast population in a larger field of view, while the images at the original magnification of 5000x were to examine the morphology of yeast cells more closely. Generally, for all the yeast strains tested, more yeast cells attached onto the substrate surface with more and larger clusters at the lower nMgO concentrations. At the higher $\mathrm{nMgO}$ concentrations, less yeast cells attached onto the surface, the clusters were smaller, and more yeasts appeared in the form of isolated individual cell. For C. albicans, both pseudohyphae and yeast cells were 


\section{C. albicans FR}
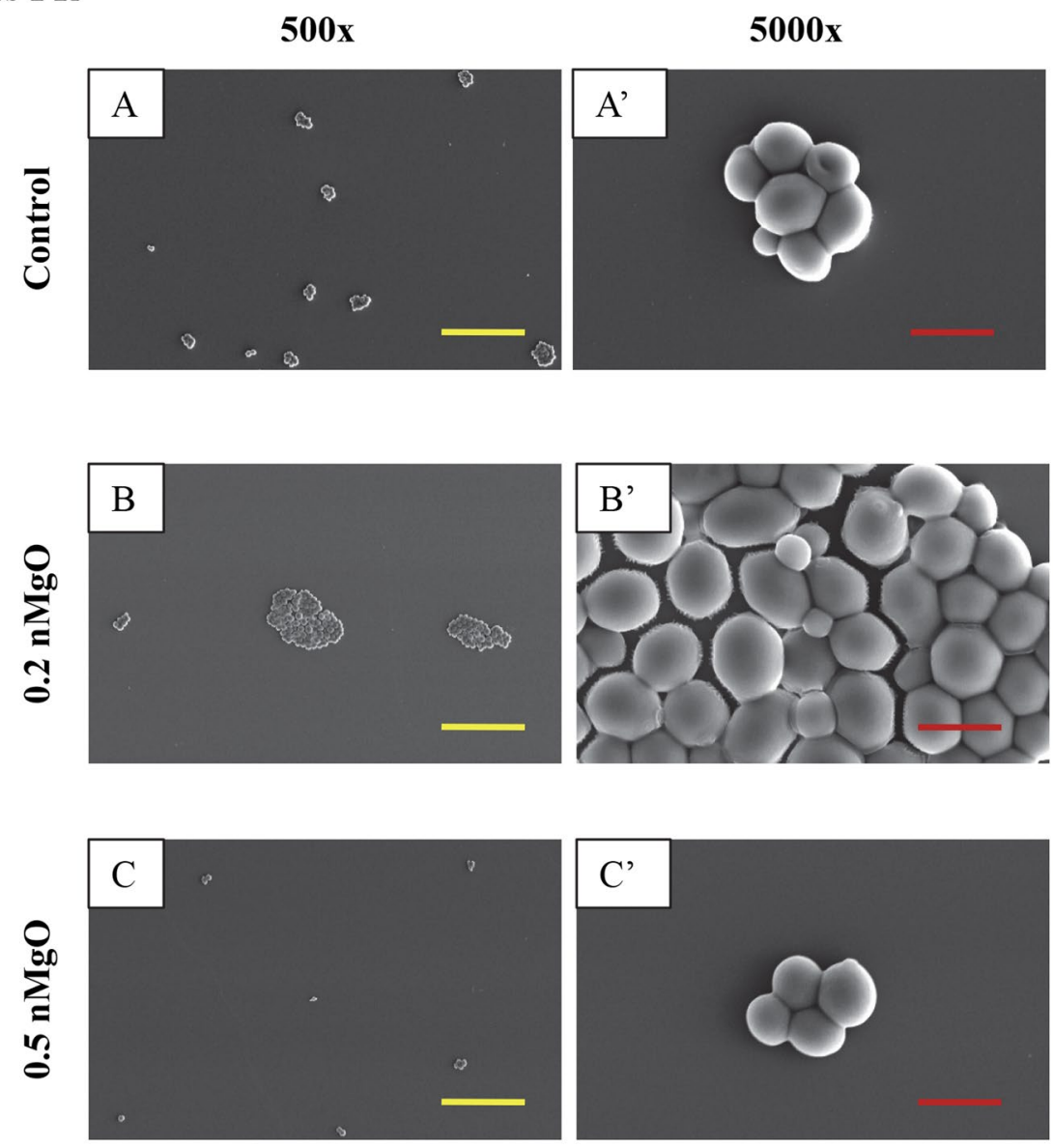

Figure 7. SEM images of C. albicans FR, showing its morphology after 24 hours of culture with $0-2.0 \mathrm{mg} / \mathrm{mL}$ of $\mathrm{nMgO}$. (A to $\mathbf{C}$ ) Images at an original magnification of 500x with a scale bar of $50 \mu \mathrm{m}$. (A' to $\mathbf{C}^{\prime}$ ) Images at an original magnification of $5000 \mathrm{x}$ with a scale bar of $5 \mu \mathrm{m}$. At higher concentrations of $\mathrm{nMgO}(>0.5 \mathrm{mg} / \mathrm{mL})$, very few adhered C. albicans (FR) were found, and thus images are not shown for the higher nMgO concentrations.

present at the lower $\mathrm{nMgO}$ concentrations (i.e., $0-0.7 \mathrm{mg} / \mathrm{mL}$ ); at $1.0 \mathrm{mg} / \mathrm{mL}$ of $\mathrm{nMgO}$ and above, very few yeast cells (without pseudohyphae) were found on the substrate and some showed membrane damage (Fig. 6). In contrast to drug-sensitive C. albicans, C. albicans FR showed mainly oval-shaped morphology and aggregated to form nearly spherical clusters without pseudohyphae (Fig. 7). At $0.5 \mathrm{mg} / \mathrm{mL}$ of $\mathrm{nMgO}$ and above, very few C. albicans FR attached on the substrate. For C. glabrata, only oval-shaped yeast cells were observed (Fig. 8), because C. glabrata in nature does not form pseudohyphae ${ }^{36}$. Interestingly, when compared with the control group without $\mathrm{nMgO}$ $(0 \mathrm{mg} / \mathrm{mL})$, the numbers of $C$. glabrata attached onto the substrate surface increased at the nMgO concentrations of $0.2-0.7 \mathrm{mg} / \mathrm{mL}$ and decreased when the $\mathrm{nMgO}$ concentrations increased to $1.0 \mathrm{mg} / \mathrm{mL}$ and above. At 0.5 and $0.7 \mathrm{mg} / \mathrm{mL}$ of $\mathrm{nMgO}$, the C. glabrata formed smaller clusters or appeared as isolated individual cell when compared with the group at $0.2 \mathrm{mg} / \mathrm{mL}$ of $\mathrm{nMgO}$ (Fig. 8). When the $\mathrm{nMgO}$ concentrations increased to $1.0 \mathrm{mg} / \mathrm{mL}$ and above, very few C. glabrata cells attached onto the substrate surface. When compared with C. glabrata, C. glabrata ER showed some damage in membrane as the $\mathrm{nMgO}$ concentrations increased (Fig. 9). When the $\mathrm{nMgO}$ concentrations increased, the number of attached C. glabrata ER decreased, and the clusters were fewer and smaller in size.

MgO nanoparticles disrupted S. epidermidis biofilm. Magnesium oxide nanoparticles disrupted S. epidermidis biofilm. Before the addition of $\mathrm{nMgO}$, we confirmed that there were indeed biofilms formed on the glass substrate (Fig. 10A). However, at 24 hours after the addition of $1.6 \mathrm{mg} / \mathrm{mL}$ of nMgO into the culture, no biofilm was found at both 1000x and 5000x, indicating that $\mathrm{nMgO}$ disrupted the biofilm (Fig. 10A). Moreover, very few cells attached onto the substrate; and, the few cells found were in the form of individual cell or small clusters of several cells, as shown in Fig. 10A. In contrast, for the control group where no nMgO was added, the biofilm not only remained, but also grew and secreted more extracellular matrix (Fig. 10A). The absorbance reading of the crystal violet $(\mathrm{CV})$ stain further confirmed the disruption of the S. epidermidis biofilm with the addition of $\mathrm{nMgO}$ ( $+\mathrm{nMgO}$ group), when compared with the control group (without adding $\mathrm{nMgO}$ ) (Fig. 10B). Lower absorbance of $\mathrm{CV}$ indicated lower concentration of $\mathrm{CV}$ bound to bacteria and thus indicated less bacteria. After the S. epidermidis biofilm was cultured with $1.6 \mathrm{mg} / \mathrm{mL}$ of $\mathrm{nMgO}$ for 24 hours, the $\mathrm{nMgO}$ particles were washed away from the culture before the bacteria were stained with $\mathrm{CV}$, which eliminated any possible effects of $\mathrm{nMgO}$ on the absorbance readings. 


\section{C. glabrata}
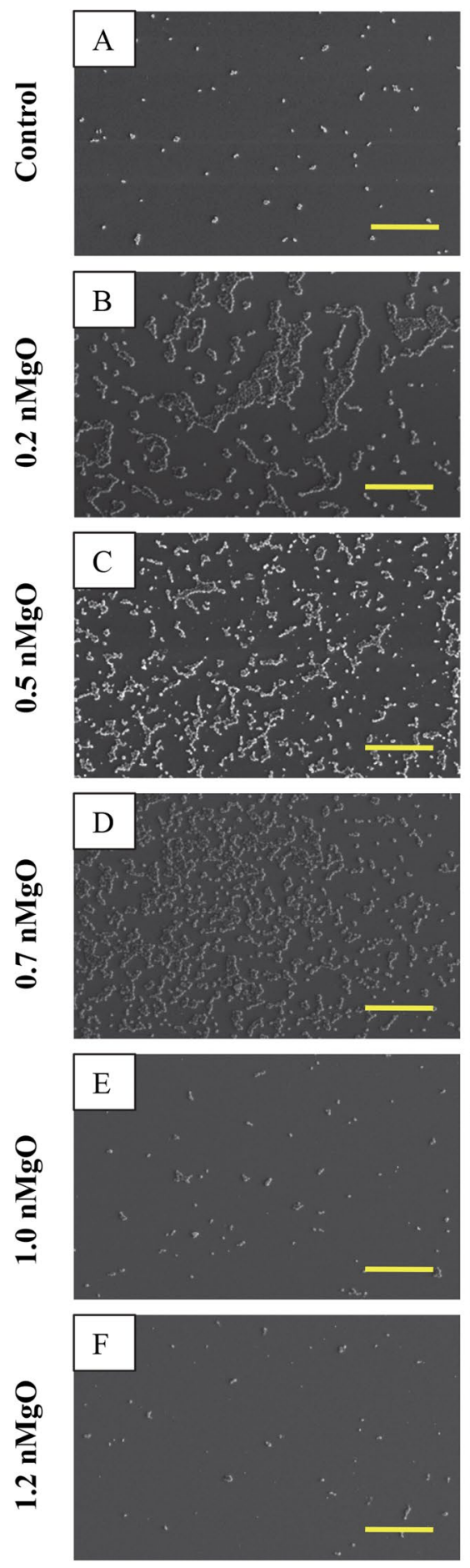

5000x
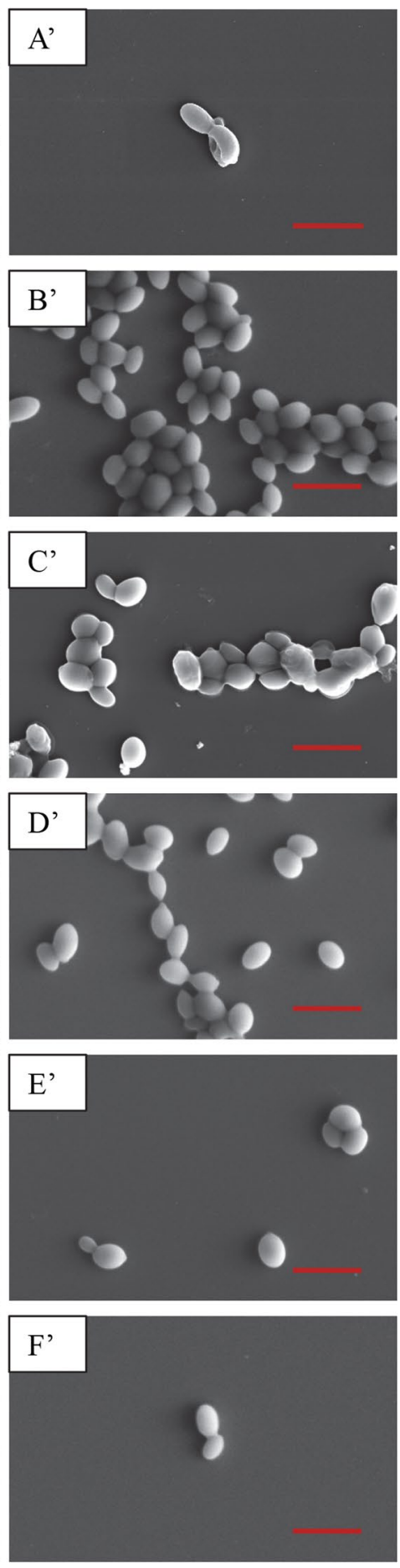

Figure 8. SEM images of C. glabrata, showing its morphology after 24 hours of culture with $0-2.0 \mathrm{mg} / \mathrm{mL}$ of nMgO. (A to E): Images at an original magnification of 500x with a scale bar of $50 \mu \mathrm{m}$. (A' to E') Images at an original magnification of $5000 \mathrm{x}$ with a scale bar of $5 \mu \mathrm{m}$. At $1.2-2.0 \mathrm{mg} / \mathrm{L} \mathrm{nMgO}$, the cell morphology was similar, thus only one image at each magnification at $1.2 \mathrm{mg} / \mathrm{mL} \mathrm{nMgO}$ is shown as a representative for those at the higher $\mathrm{nMgO}$ concentrations.

The effects of $\mathrm{pH}$ and $\mathrm{Mg}^{2+}$ ions on S. epidermidis. Both the higher $\mathrm{pH}$ of 7-10 and higher $\mathrm{Mg}^{2+}$ ion concentrations up to $50 \mathrm{mM}$ in TSB did not reduce the viability of S. epidermidis (Figs 11 and 12). There was bacterial growth in all groups of $\mathrm{pH}$ from 7-10; and the CFUs were statistically higher for the groups with the broth $\mathrm{pH}$ initially adjusted to 7.5-10 than the control group with the normal broth $\mathrm{pH}$ of 7 . The results of this $\mathrm{pH}$ study confirmed that the alkaline $\mathrm{pH}$ was not a contributor to the observed bacterial death when cultured 


\section{C. glabrata ER}
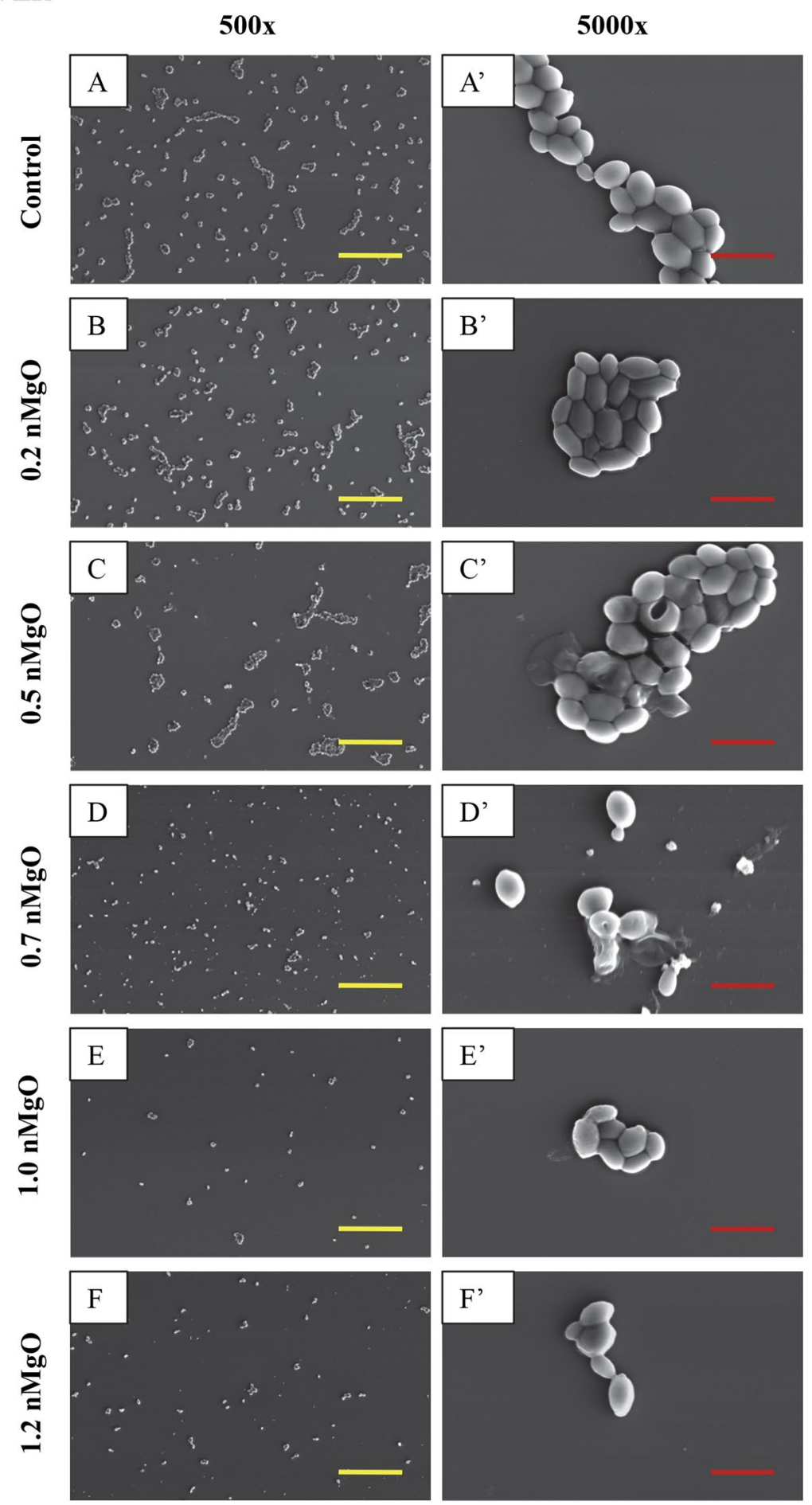

Figure 9. SEM images of C. glabrata ER, showing its morphology after 24 hours of culture with $0-2.0 \mathrm{mg} / \mathrm{mL}$ $\mathrm{nMgO}$. (A to E) Images at an original magnification of $500 \mathrm{x}$ with a scale bar of $50 \mu \mathrm{m}$. (A' to $\mathbf{E}^{\prime}$ ) Images at an original magnification of $5000 \mathrm{x}$ with a scale bar of $5 \mu \mathrm{m}$. At $1.2-2.0 \mathrm{mg} / \mathrm{mL} \mathrm{nMgO}$, the cell morphology was similar, and thus only one image at each magnification at $1.2 \mathrm{mg} / \mathrm{mL} \mathrm{nMgO}$ is shown as a representative for those at the higher nMgO concentrations.

with $\mathrm{nMgO}$, even though the dissociation of $\mathrm{nMgO}$ in bacterial cultures caused $\mathrm{pH}$ increase. Despite the $\mathrm{pH}$ of TSB was initially adjusted to a higher value of 7 to 10 in alkaline region, the post-culture broth pH reduced to $5.3-8.3$ respectively when bacteria grew over the 24 hours of culture (Fig. 11B). For example, when the broth $\mathrm{pH}$ was initially adjusted to 8.5 , the post-culture broth $\mathrm{pH}$ reduced to 6 . The reduction of post-culture $\mathrm{pH}$ confirmed 
A
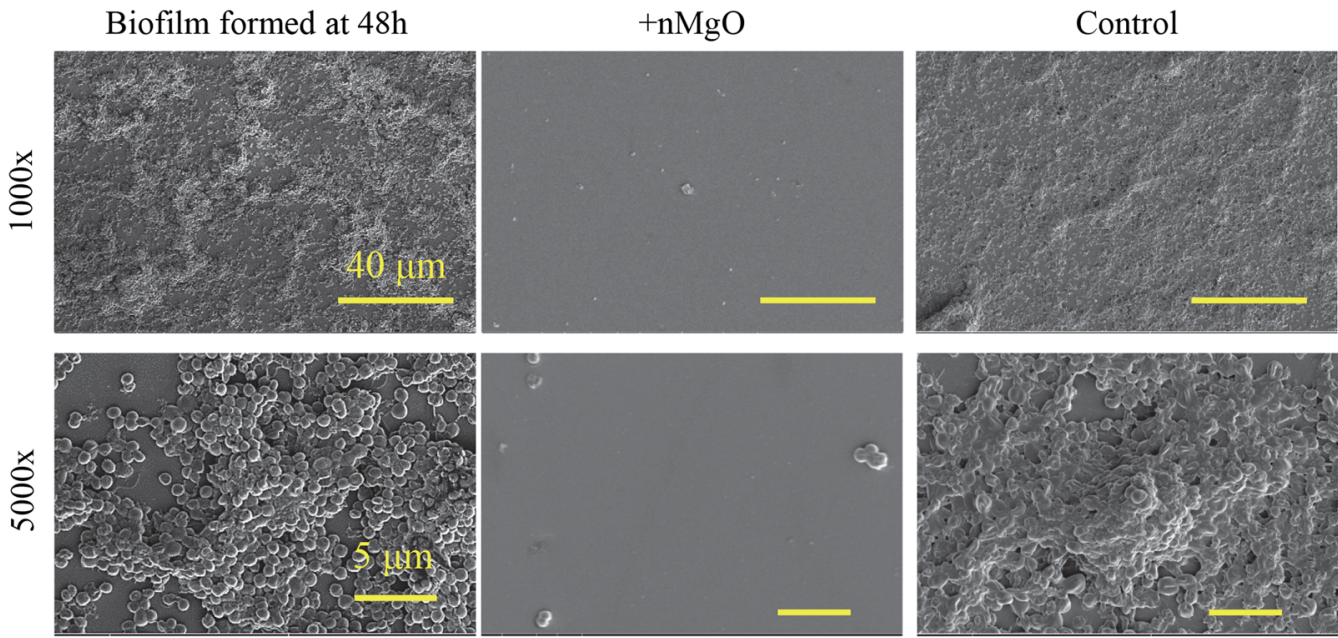

B

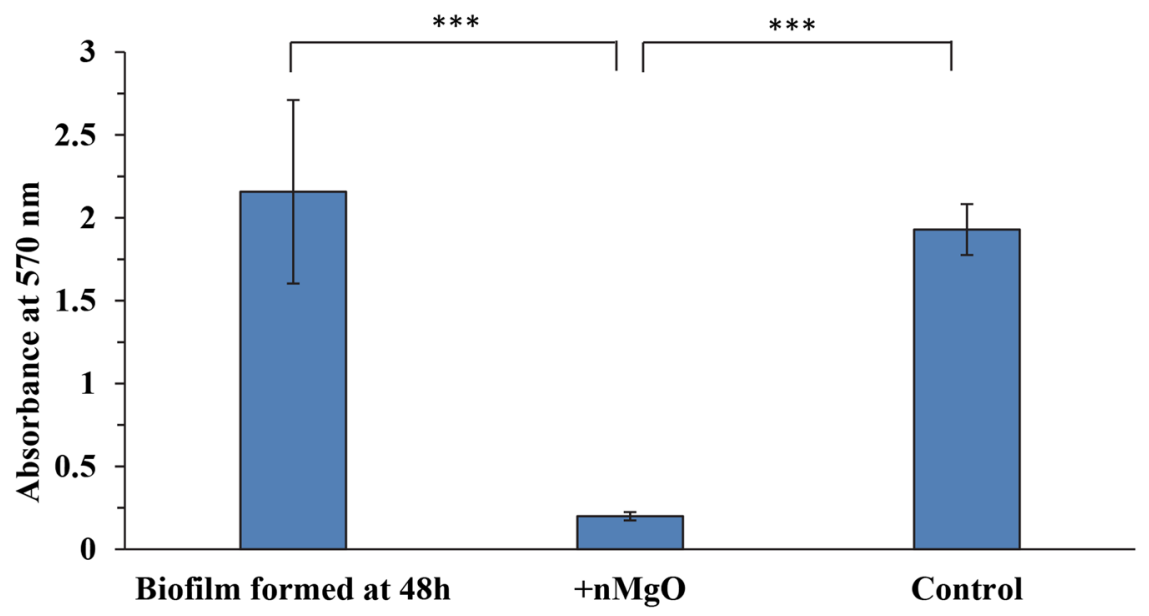

Figure 10. Addition of $\mathrm{nMgO}$ disrupted S. epidermidis biofilm. (A) SEM images of S. epidermidis on glass confirmed the formation of biofilm at the 48 hours of culture and the disruption of biofilm when $\mathrm{nMgO}$ was added after 48 hours of culture and cultured for additional 24 hours. The original magnification was 1000x with a scale bar of $40 \mu \mathrm{m}$ and $5000 \mathrm{x}$ with a scale bar of $5 \mu \mathrm{m}$. (B) Crystal violet absorbance at $570 \mathrm{~nm}$. When the biofilm formed after 48 hours of culture, $1.6 \mathrm{mg} / \mathrm{mL}$ of $\mathrm{nMgO}$ was added into one group and another group served as the control without $\mathrm{nMgO}$ being added. Both the group with $\mathrm{nMgO}$ (denoted as $+\mathrm{nMgO}$ ) and the control group without $\mathrm{nMgO}$ were cultured for additional 24 hours. Indicates $* * * p \leq 0.0005$.

continuous growth of bacteria, because bacteria released acidic metabolites when they grew. In the $\mathrm{pH}$ study, the $\mathrm{Mg}^{2+}$ concentration remained the same across the different initial $\mathrm{pH}$ groups (Fig. 11C) and the $\mathrm{Ca}^{2+}$ showed a slight decreasing trend as the initial pH increased (Fig. 11D).

When S. epidermidis was cultured in the broth with supplemental dosages of $1-50 \mathrm{mM} \mathrm{Mg}^{2+}$ ions, bacteria showed clear growth. The $\mathrm{pH}$ of post-culture broth reduced to 5.3-5.4 from the initial $\mathrm{pH}$ of 7.3 for all of the groups with supplemental $\mathrm{Mg}^{2+}$ dosages, indicating the bacteria continued to grow and release acidic metabolites. Interestingly, in the doped $\mathrm{Mg}^{2+}$ ion study, the $\mathrm{Ca}^{2+}$ increased (Fig. 12D) as the concentration of $\mathrm{Mg}^{2+}$ increased (Fig. 12C). This suggested that $\mathrm{Mg}^{2+}$ concentration could affect the $\mathrm{Ca}^{2+}$ concentration in the broth. It is important to note that the $\mathrm{Mg}^{2+}$ ion concentrations in the post-culture broths were close to the initially doped amount of $\mathrm{Mg}^{2+}$ ions.

\section{Discussions}

Comparability of antimicrobial activities of $\mathrm{nMgO}$ against different microorganisms.

Antimicrobial properties of $\mathrm{MgO}$ have been reported in literature, but these studies involved different experimental techniques, varying size and concentrations of particles, and different concentrations of initial bacterial seeding density ${ }^{14,15,17,37}$. For example, Krishnamoorthy et al. reported the minimal inhibition concentration (MIC) of $\mathrm{nMgO}$ at the size of 10-30 nm against Escherichia coli (E. coli), Pseudomonas aeruginosa (P. aeruginosa), and Staphylococcus aureus (S. aureus) using microtiter plate-based method with a bacteria seeding density of $5 \times 10^{5} \mathrm{CFU} / \mathrm{mL}^{17}$. Jin et al. tested $\mathrm{nMgO}$ at the size of $20 \mathrm{~nm}$ in the concentrations of $1-8 \mathrm{mg} / \mathrm{mL}$ against $10^{4}$ and 

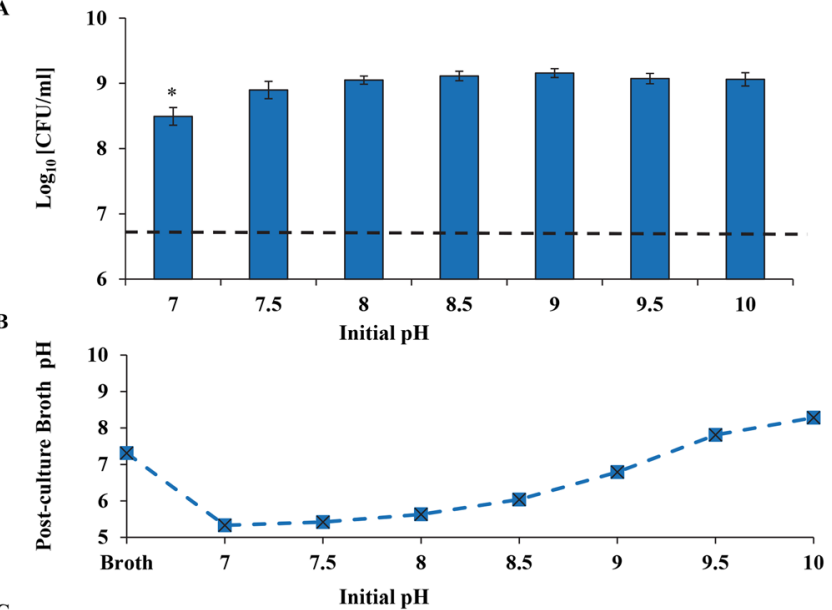

C
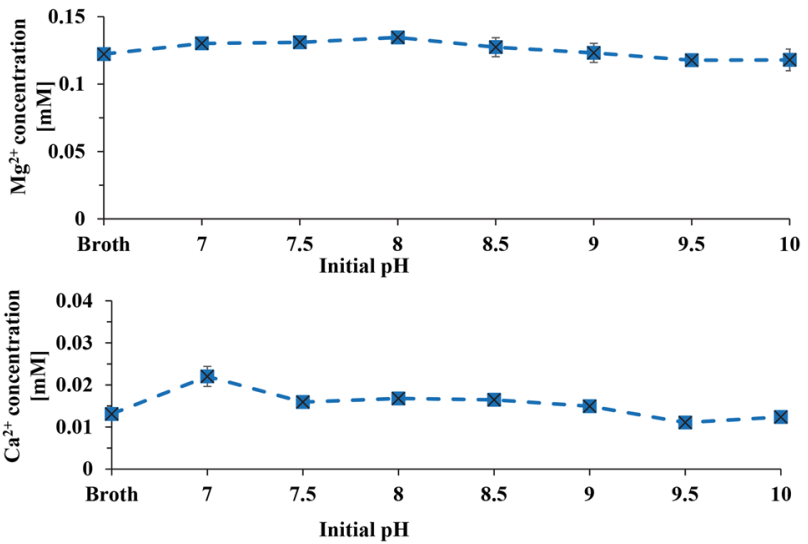

Figure 11. The effects of adjusted initial $\mathrm{pH}$ of broths on S. epidermidis. (A) The CFUs of S. epidermidis after 24 hours of culture in the broths with adjusted initial $\mathrm{pH}$ values of $7-10$. (B) Post-culture broth $\mathrm{pH}$. (C) $\mathrm{Mg}^{2+}$ ion concentrations in the post-culture broths. (D) $\mathrm{Ca}^{2+}$ ion concentrations in the post-culture broths. Broth indicates the TSB only and serves as a blank reference of broth without bacteria. Dash line in panel A represents the initial S. epidermidis seeding density.

$10^{8} \mathrm{CFU} / \mathrm{mL}$ of E. coli $0157: \mathrm{H} 57$ in a test tube ${ }^{15}$. Jin et al. showed that the higher nMgO concentration was more efficient in eliminating food-borne pathogens. Monzavi et al. reported fungicidal activity of $10 \mathrm{mg} / \mathrm{L} \mathrm{nMgO}$ with a size range of 70-150 nm against oral Candida albicans (C. albicans) using a tube broth dilution assay for endodontic applications ${ }^{37}$. Sawai et al. performed a halo test on agar plates to determine the antimicrobial properties of $\mathrm{MgO}$ at the size of $3.6 \mu \mathrm{m}$ and concentration of $100 \mathrm{mg} / \mathrm{mL}$ against $E$. coli and $S$. aureus with a seeding density of $\sim 10^{9} \mathrm{CFU} / \mathrm{mL}^{14}$. The techniques used in these studies were all different, including microtiter assay, macro dilution assay in test tubes, and agar diffusion assay. The agar diffusion assay involves direct interaction of the nanoparticles with the bacteria on the agar surface, which differs from the interactions of bacteria and nanoparticles in the broth suspensions such as those in microtiter assay and macro dilution assay in test tubes. In the agar diffusion assay, the bacteria are stationary on the surface of the agar, while in broth suspension, the motile bacteria such as Pseudomonas species can move. Even though all different methods used by different researchers showed that $\mathrm{nMgO}$ is antimicrobial, the results of Sawai et al. using agar diffusion assay could not be directly compared with the results from Krishnamoorthy et al. who did microtiter assay or Jin et al. who performed test tube experiment. Furthermore, different methods were used for quantifying antimicrobial activities of $\mathrm{nMgO}$ in these studies, which made the results against different bacterial strains not directly comparable and thus inapplicable toward clinical translation.

The size of nanoparticles may also affect their antimicrobial properties. For example, the smaller silver nanoparticles exhibited higher efficiencies against different organisms ${ }^{38}$. Thus, it is very likely that the size of nMgO would also affect its antimicrobial activities. The antimicrobial properties of $\mathrm{nMgO}$ with the size of $20 \mathrm{~nm}$ might not be directly comparable with $\mathrm{nMgO}$ with the size of $150 \mathrm{~nm}$ or $3.6 \mu \mathrm{m}$. Moreover, nanoparticles have strong tendency to agglomerate in the broth suspension because of their high surface energy, which could affect the interactions of these nanoparticles with bacteria or yeasts. Despite of constant shaking in the shaker incubator, it is still likely that some $\mathrm{nMgO}$ formed agglomerates in the cultures with bacteria or yeasts.

The initial seeding densities of bacteria varied from $10^{4}$ to $10^{9} \mathrm{CFU} / \mathrm{mL}$ in the previous studies ${ }^{14,15,17,18}$, which could be another factor that had played a role in the antimicrobial results. For example, Wetteland et al. reported the MIC and $\mathrm{MBC}_{90}$ of $\mathrm{nMgO}$ was $1.2 \mathrm{mg} / \mathrm{mL}$ against $E$. coli, and $\mathrm{MIC}$ of $0.7 \mathrm{mg} / \mathrm{mL}$ and $\mathrm{MBC}_{90}$ of $1.2 \mathrm{mg} / \mathrm{mL}$ against $S$. epidermidis ${ }^{18}$, which were greater than the respective values found in this study, even though the same 
A
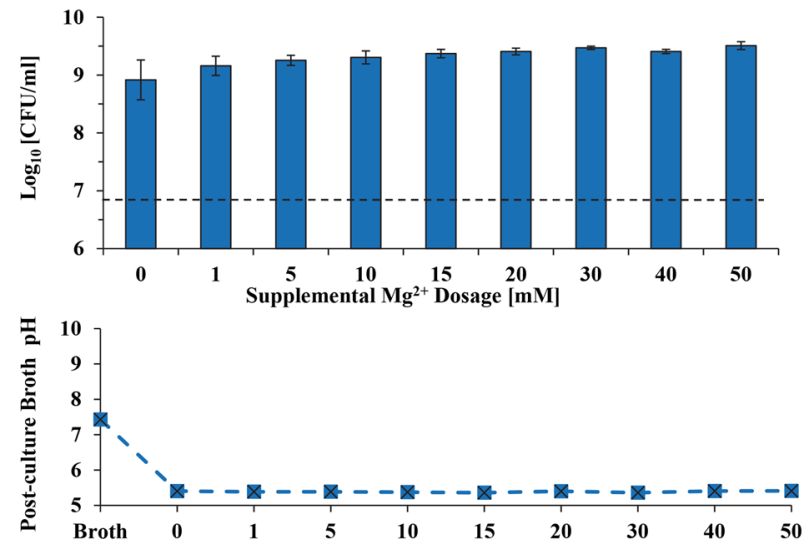

C

Supplemental $\mathrm{Mg}^{2+}$ Dosage $[\mathrm{mM}]$

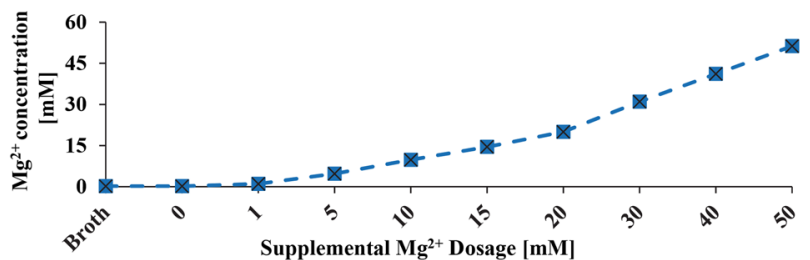

D

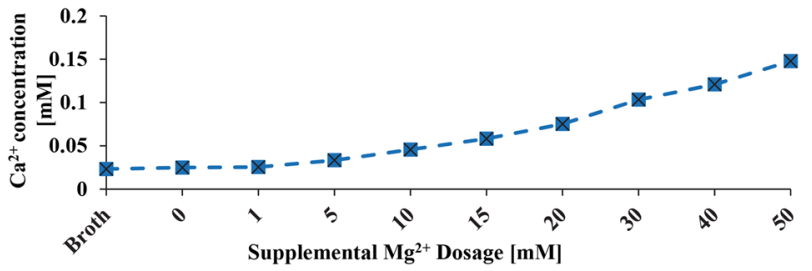

Figure 12. The effects of $\mathrm{Mg}^{2+}$ ion doped broths on S. epidermidis. (A) The CFUs of S. epidermidis after 24 hours of culture in the broths with supplemental $\mathrm{Mg}^{2+}$ dosages of $0-50 \mathrm{mM}$. (B) Post-culture broth $\mathrm{pH}$. (C) $\mathrm{Mg}^{2+}$ ion concentrations in the post-culture broths. (D) $\mathrm{Ca}^{2+}$ ion concentrations in the post-culture broths. Broth indicates the TSB only and serves as a blank reference of broth without bacteria. Dash line in panel A represents the initial S. epidermidis seeding density.

experimental techniques and the same $\mathrm{nMgO}$ of the same size were used by Wetteland et al. and the only difference was the initial seeding density. Wetteland et al. used the seeding density of $5 \times 10^{5} \mathrm{CFU} / \mathrm{mL}$, an order of magnitude lower than the seeding density of $(6-8) \times 10^{6} \mathrm{CFU} / \mathrm{mL}$ used in this study. Bacteria could behave differently at different seeding densities because of quorum sensing ${ }^{39}$, which possibly contributed to the different $\mathrm{MIC}$ and $\mathrm{MBC}$ values reported for $\mathrm{nMgO}$ by Wetteland et al. ${ }^{18}$. We chose $(6-8) \times 10^{6}$ bacteria/mL or yeasts/ $\mathrm{mL}$ as the seeding density in this study because this was reported to be the critical density causing urinary tract infection, one of the most frequently occurred infections in medical implants and devices ${ }^{40,41}$. However, the exact mechanisms explaining how the bacterial seeding density affected MIC and MBC of nMgO are still unknown and should be further studied to determine if quorum sensing indeed played a key role.

In this study, microorganisms of the same seeding density were tested with $\mathrm{nMgO}$ of the same size and same concentration range using the same experimental method, which made it possible to directly compare the antimicrobial properties of $\mathrm{nMgO}$ against different microorganisms. Because of these consistent parameters, the results of this study are valuable for translating $\mathrm{nMgO}$ toward medical device applications that typically involve a wide range of pathogenic microbes.

Comparing the antimicrobial activities of $\mathrm{nMgO}$ against gram-negative bacteria, gram-positive bacteria, and yeasts. The $\mathrm{MBC}$ of $\mathrm{nMgO}$ varied for different gram-positive and gram-negative bacteria tested. Gram-positive and gram-negative bacteria mainly differ in their cell wall structure. Gram-negative bacteria have a thin peptidoglycan layer with an outer membrane containing lipopolysaccharides (LPS), while gram-positive bacteria have a thick layer of peptidoglycan without outer membrane and contain teichoic acids. Due to these major differences, each type of bacteria may display diverse sensitivities to antimicrobial agents. When the $\mathrm{nMgO}$ concentrations were greater than $1.6 \mathrm{mg} / \mathrm{mL}$, no viable gram-negative bacteria $E$. coli and less than $0.1 \%$ viable $P$. aeruginosa were detected, but not in the cases for gram-positive bacteria $S$. epidermidis, $S$. aureus or MRSA. Interestingly, the MIC of nMgO was lower for S. epidermidis and S. aureus than for E. coli and $P$. aeruginosa, suggesting that $\mathrm{nMgO}$ with increasing concentrations might be inhibitory against the growth of gram-positive bacteria and lethal against gram-negative bacteria. 
Unlike bacteria, yeasts are eukaryotic cells. Yeasts have both a fungal cell wall and a cell membrane. Most antifungal drugs target the molecules in the cell wall or the cell membrane ${ }^{42}$. There are three main classes of antifungals: echinocandin, azole and polyenes. Among the antifungals in the class of azoles, fluconazole was widely used for treating infections caused by C. albicans ${ }^{43}$. Fluconazole serves as an antifungal drug by interfering the synthesis of ergosterol, a key component in the cell membrane ${ }^{44}$. Resistance to this antifungal drug has emerged due to its excessive usage ${ }^{43}$. We included $C$. albicans $F R$ strain in this study to determine whether or not $\mathrm{nMgO}$ would exhibit detrimental effects on the fluconazole resistant C. albicans strain. Indeed, not only C. albicans but also C. albicans FR was sensitive to antifungal activities of $\mathrm{nMgO}$. Interestingly, a possible paradoxical effect on C. albicans and C. albicans $F R$ was observed; at $2.0 \mathrm{mg} / \mathrm{mL}$ of $\mathrm{nMgO}$, the numbers of viable C. albicans and $C$. albicans FR (CFUs) were similar to that of the control group without $\mathrm{nMgO}$, indicating no inhibition or killing action against both yeast strains at the highest concentrations of $\mathrm{nMgO}$ in this study. A paradoxical effect occurs when the antifungal agent showed no inhibition or killing of the yeasts at the concentrations well above the MIC levels ${ }^{45}$. This paradoxical effect has not been reported for $\mathrm{nMgO}$ in literature. The reason for the paradoxical effect is still unknown and this phenomenon should be further investigated in the future.

Most yeast infections are caused by C. albicans; however, infections caused by C. glabrata have been increasing globally over the past decade, such as healthcare associated candidemia infections ${ }^{46,47}$. C. glabrata strains have been reported to develop rapid and increasing resistance to the widely-used antifungal drugs such as the classes of echinocandin, with the increasing use of echinocandin for treating candida infections ${ }^{46,48,49}$. Therefore, we examined the effects of $\mathrm{nMgO}$ against drug-sensitive and drug-resistant strains of C. glabrata, and found that $\mathrm{nMgO}$ was fungicidal to both C. glabrata and C. glabrata ER. C. albicans was generally more resistant to nMgO than C. glabrata, which could be due to the ability of $C$. albicans in forming pseudohyphae and hyphae during their growing phase $\mathrm{s}^{30}$. C. glabrata is the only one among all the Candida species that does not make pseudohyphae above $37^{\circ} \mathrm{C}^{36}$. When C. albicans form pseudohyphae during their growth, more $\mathrm{nMgO}$ would be required to kill them. In contrast, $C$. glabrata cells retained their oval morphology without forming pseudohyphae when exposed to $\mathrm{nggO}$, and thus may require less $\mathrm{nMgO}$ to kill them. In the SEM images in Fig. 6, there were more yeast cells than pseudohyphae with increasing $\mathrm{nMgO}$ concentrations, suggesting that $\mathrm{nMgO}$ suppressed surviving yeasts from forming the pseudohyphae. Further research is needed to understand if nMgO inhibits the formation of pseudohyphae.

In summary, Table 2 shows the MICs and MLCs of nMgO at 90\%, 99\%, 99.9\%, 99.99\% of killing and the most potent concentration (MPC) of $\mathrm{nMgO}$ for all microorganisms studied. Table 2 provides important guidelines for utilizing $\mathrm{nMgO}$ in a specific application against a specific microorganism of interest. For example, gram-negative bacteria release lipopolysaccharides (LPS), when they are killed. LPS is an endotoxin that could cause sepsis and inflammation especially at high concentrations, by inducing the production of TNF- $\alpha$, one of the main pro-inflammatory cytokines ${ }^{50,51}$. In many cases, it may not be desirable to kill the whole bacteria population, but rather to kill enough of them (e.g. 90-99\% of death) or inhibit their activities to eliminate the infections without harmful side effects associated with excess and rapid release of LPS. The $\mathrm{nMgO}$ may be used in the form of a coating on a medical device or as an additive in a composite material for a medical device, where the $\mathrm{nggO}$ could provide antimicrobial properties against infections without significant side effects. Further studies are needed to determine if the high concentrations of $\mathrm{nMgO}$ at MIC, MLC, or MPC level can be integrated into medical devices to achieve desired antimicrobial responses without harming host cells and tissues.

Integration of $\mathrm{nMgO}$ with medical devices could provide the devices with sustainable antimicrobial properties while mitigating the toxicity concern regarding burst of high concentrations of $\mathrm{nMgO}$. At lower concentration, the $\mathrm{nMgO}$ nanoparticles increased BMSC adhesion density and proliferation ${ }^{18}$, which is beneficial for bone healing and regeneration. However, the $\mathrm{nMgO}$ concentrations ranged from $0-2 \mathrm{mg} / \mathrm{mL}$ in this study with the most potent concentrations (MPC) of $1.4 \mathrm{and} / \mathrm{or} 1.6 \mathrm{mg} / \mathrm{mL}$, which are considered high and even toxic to some mammalian cells ${ }^{18}$ if $\mathrm{nMgO}$ is used as an antibiotic drug. However, for the clinical applications where $\mathrm{nMgO}$ is used in antimicrobial coatings on indwelling medical devices or as an antimicrobial additive in polymer or ceramic based biocomposites for medical devices, this study provided valuable knowledge on the concentration effects of $\mathrm{nMgO}$ on the viability of 9 major pathogenic bacteria and yeasts. The results of this study, together with the previous results on the concentration effects of $\mathrm{nMgO}$ on $\mathrm{BMSCs}^{18}$, presented valuable design guidelines for incorporating $\mathrm{nMgO}$ into medical devices and implants, thus reducing implant-associated infections. Even though antibiotics and antifungals have been widely used in clinical practice, post-operative infections still occur, especially involving indwelling medical devices, and many of these infections and associated microbes are drug resistant. So far, there are no reports of microorganisms being resistant to $\mathrm{nMgO}$. Moreover, $\mathrm{nMgO}$ is attractive as an additive or coating material for next-generation biodegradable medical devices and implants because nMgO nanoparticles are biodegradable in the body and dissociate into $\mathrm{Mg}^{2+}$ ions that are beneficial for tissue healing, in addition to providing desirable antimicrobial properties.

Possible action mechanisms for $\mathrm{nMgO}$ against bacteria and yeasts. The antimicrobial mechanisms of $\mathrm{nMgO}$ have been proposed and debated, and currently there is no consensus yet. Figure 13 illustrates the possible mechanisms of $\mathrm{nMgO}$ against bacteria. There were some speculations that elevated $\mathrm{pH}$ and $\mathrm{Mg}^{2+}$ ions could play a role in the action mechanisms of $\mathrm{nMgO}$, considering that $\mathrm{nMgO}$ dissociated in bacterial or yeast culture and released $\mathrm{OH}^{-}$ions and $\mathrm{Mg}^{2+}$ ions. As the concentrations of $\mathrm{nMgO}$ increased from $0-2.0 \mathrm{mg} / \mathrm{mL}$, more $\mathrm{nMgO}$ dissociated, resulting in more $\mathrm{OH}^{-}$ions and increased broth $\mathrm{pH}$. However, based on our studies on S. epidermidis, the increased $\mathrm{pH}$ and $\mathrm{Mg}^{2+}$ ions in the broths were not the main contributing factors for antimicrobial activities of $\mathrm{nMgO}$. Specifically, the growth of $S$. epidermidis was not affected when they were cultured in the broths with pH intentionally adjusted to 7-10; and, the deliberate doping of $\mathrm{Mg}^{2+}$ ions in the broths up to $50 \mathrm{mM}$ did not cause adverse effects on the viability of $S$. epidermidis. The results reported in literature are in agreement with ours. For example, Sawai et al. reported that $\mathrm{pH}$ of $10.5 \mathrm{did}$ not affect the growth of $E$. coli $i^{14}$. Wetteland et al. reported that the $\mathrm{pH}$ ranged at 7-10 and supplemental $\mathrm{Mg}^{2+}$ ions ranged at $1-50 \mathrm{mM}$ did not affect the growth of E. coli and S. epidermidis ${ }^{18}$. 


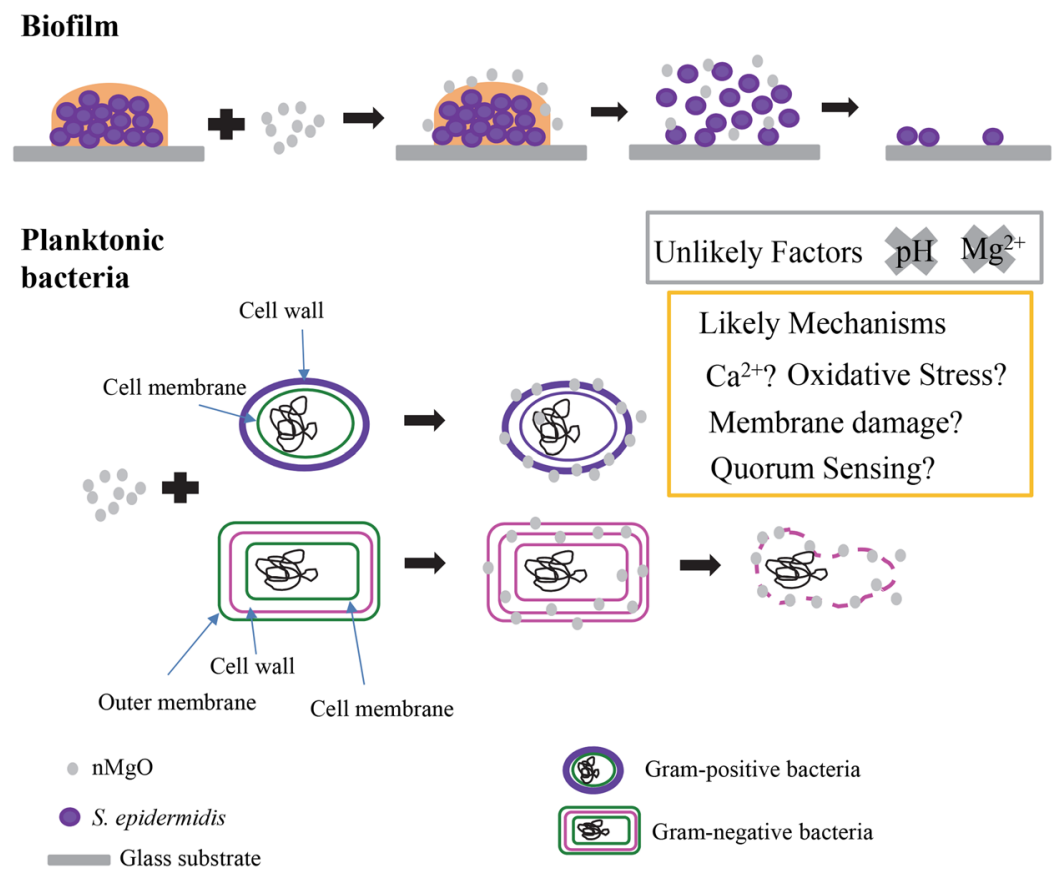

Figure 13. A schematic illustration of the possible mechanisms of $\mathrm{nMgO}$ against planktonic bacteria and bacterial biofilm. Oxidative stress, $\mathrm{Ca}^{2+}$ ion concentrations, membrane damage, and quorum sensing are the possible mechanisms of $\mathrm{nMgO}$ against planktonic bacteria, but alkaline $\mathrm{pH}$ of 7 to 10 or increased $\mathrm{Mg}^{2+}$ ion concentrations from 1 to $50 \mathrm{mM}$ showed no inhibitory or killing effects on bacteria such as S. epidermidis.

$\mathrm{Ca}^{2+}$ ion concentrations in the broths showed interesting correlations with the nMgO concentrations, the supplemental $\mathrm{Mg}^{2+}$ ion dosages, and the CFUs of bacteria and yeasts (Figures S1-S4 in Supplementary Materials), which suggested that the dissociation of $\mathrm{nMgO}$ to $\mathrm{Mg}^{2+}$ ions might have played a role on the $\mathrm{Ca}^{2+}$ ion concentrations in the cultures. To our knowledge, these correlations have not been previously reported in literature and further research is needed to fully understand the specific roles of $\mathrm{Ca}^{2+}$ ions in the bacterial or yeast cultures with $\mathrm{nMgO}$. Additional information is in the Supplementary Materials.

Production of reactive oxygen species (ROS) was proposed as one of the leading theories for the antimicrobial action of $\mathrm{nMgO}^{14,17}$. However, Leung et al. showed that $\mathrm{nMgO}$ inhibited $E$. coli growth without the presence of ROS $^{52}$. Nevertheless, ROS might still be one possible mechanism for the antimicrobial action of nMgO for the following reasons. Bacteria that undergo aerobic respiration will generate superoxide anions and other ROS, and these ROS are toxic to the bacteria. Bacteria also make superoxide dismutase (SOD) to neutralize the ROS ${ }^{53,54}$. The microorganisms studied in this paper are all aerobic, and thus they do produce SOD. The ROS generated by $\mathrm{nMgO}$ could be neutralized by the SOD produced by bacteria. However, at higher concentrations of $\mathrm{nMgO}$, more ROS could be produced and not all of the ROS could be timely neutralized by the SOD; and, the excess ROS could still cause damage to the bacteria.

Another antimicrobial mechanism of $\mathrm{nMgO}$ could be that $\mathrm{nMgO}$ particles bind to the cell membrane to cause damage ${ }^{15,52}$. Membrane damage was observed in E. coli when they were cultured with the higher dosages of $\mathrm{nMgO}$ (Fig. 4). MgO nanoparticles caused obvious change in the morphology of $E$. coli. The gram-negative bacteria have thinner layer of peptidoglycan, and $\mathrm{nMgO}$ could pass the cell wall and bind to the cell membrane, thus causing the shape distortion and cell death as shown in E. coli. It is also possible that $\mathrm{nMgO}$ particles might accumulate on the thin peptidoglycan layer in the cell wall of gram-negative bacteria and thus damage this thin defense layer of gram-negative bacteria. Whereas in the gram-positive bacteria, considering that the zeta potential of $\mathrm{nMgO}$ is positive (Table 1), the positively charged $\mathrm{nMgO}$ particles may interact with the negatively charged phosphate groups on the teichoic acid end. If some $\mathrm{nMgO}$ did not interact with the phosphate groups, they will be stuck in the thick peptidoglycan layer of the gram-positive bacteria and does not pass through this thick defense layer of gram-positive bacteria to cause further damage. Thus, the membrane damage was observed in the gram-negative bacteria but not in the gram-positive bacteria. No membrane damage was observed in the SEM images of $P$. aeruginosa; however, this does not mean no membrane damage occurred. It is possible that $P$. aeruginosa with membrane damage could not adhere to the glass substrate, thus not shown in the SEM images. When the growth of $P$. aeruginosa was inhibited at the MIC of $1.0 \mathrm{mg} / \mathrm{mL} \mathrm{nMgO}$, a small portion of viable $P$. aeruginosa could still adhere onto the glass substrate. Interestingly, $\mathrm{nMgO}$ was able to reduce the viability of gram-negative bacteria such as $E$. coli and $P$. aeruginosa to undetectable levels, but it was not the case for the gram-positive bacteria such as $S$. epidermidis. One possible reason is that $\mathrm{nMgO}$ caused more severe damage to the cell wall and cell membrane of gram-negative bacteria than to the gram-positive bacteria because of their different structures in the cell walls and membranes. In the case of gram-positive bacteria, $\mathrm{nMgO}$ might not be able to pass the cell wall easily due to their thicker peptidoglycan layer. The nMgO particles could be trapped in the peptidoglycan layer of gram-positive 
bacteria, thus inhibiting their growth. Teichoic acid is another component that extends from the inner side to the outer side of cell wall and exists only in the cell walls of gram-positive bacteria; and their phosphate groups may react with $\mathrm{nMgO}$ and trap $\mathrm{nMgO}$ on the outer layer of bacterial cell wall ${ }^{55}$. When the $\mathrm{nMgO}$ nanoparticles adhered to the outer layer of the cell wall, $\mathrm{nMgO}$ could also prevent the adhesion of bacteria onto the glass substrates. For example, when the growth of gram-positive S. epidermidis was inhibited at the MIC of $0.5 \mathrm{mg} / \mathrm{mL} \mathrm{nMgO}$, there was also a significant reduction in the number of $S$. epidermidis adhered to the glass substrates.

In addition, when $\mathrm{nMgO}$ killed the microbes or inhibited the microbial growth, the quorum sensing in the respective microbes might be disrupted considering that the total number of microbes reduced in the culture environment. In other words, $\mathrm{nMgO}$ might have disrupted the communications among respective bacteria or yeasts and thus inhibited their activities and functions. Quorum sensing could affect different properties of the bacteria such as virulence factors and the ability of microbes to communicate to each other, as previously described and reported in literature ${ }^{39,56-61}$. If the number of microbes does not reach a certain quorum, their communication is disrupted. The reduction of the number of microbes in culture suspension could prevent the adhesion of respective microbes to a standard substrate, because the communication or coordination of the microbes were disrupted.

There has been little research on antifungal effects of $\mathrm{nMgO}$ against yeasts. Both C. albicans and C. glabrata showed sensitivity to $\mathrm{nMgO}$. The C. albicans FR is resistant to fluconazole and fluconazole acts upon the fungal cell membrane by interfering with the synthesis of ergosterol ${ }^{44}$. The yeasts become resistant to azole drugs, either because the drug was pumped out by their efflux pumps, or because the yeasts underwent a point mutation in ERG11 that altered the target protein and thus reduced the binding affinity to the azoles ${ }^{62}$. Considering that $\mathrm{nMgO}$ showed the same MIC and MFC against both drug-sensitive C. albicans and C. albicans FR, the antifungal mechanisms for $\mathrm{nMgO}$ might be different from azoles.

While C. glabrata ER is resistant to echinocandin, and echinocandin targets the 1,3- $\beta$-D-glucan synthase, disrupting the synthesis of $1,3-\beta$-D-glucan, a component in the fungal cell wall. Yeasts can become resistant to echinocandin by having a point mutation in the FKS gene, reducing their sensitivity to echinocandin ${ }^{49}$. The $\mathrm{nMgO}$ showed greater efficacy against $C$. glabrata ER strain than against C. glabrata, indicating the point mutation in the FKS gene might have made C. glabrata ER more sensitive to $\mathrm{nMgO}$. More research is still needed to fully understand how $\mathrm{nMgO}$ kill yeasts.

We demonstrated that $\mathrm{nMgO}$ could kill planktonic bacteria and disrupt biofilms, suggesting a possibility of another mode of action for $\mathrm{nMgO}$ that has not been proposed before in literature. There are three stages in biofilm development on the surface of materials. Initially, the planktonic bacteria adhere to a material or medical device. Next, the adherent bacteria produce the extracellular matrix, proliferate and form the three-dimensional (3D) biofilm structure. Finally, the biofilm releases single or cluster of bacterial cells that can migrate to other areas to start a new site of infection ${ }^{41}$. If the initial step of bacterial adhesion is prevented, no biofilms could form; thus, one way to reduce infection is to reduce bacterial adhesion and/or inhibit their growth on the surface of a medical device. For biofilms that have already formed, the extracellular matrix protects the bacteria inside the biofilm from antibiotics, and therefore, it is much harder to treat infections involving biofilms. However, the biofilm can be treated more easily if it is disrupted. When biofilm is disrupted, dormant cells inside the biofilm become active planktonic cells, which are much easier to be killed by antibiotics than bacteria inside a biofilm. Our results showed that $\mathrm{nMgO}$ could kill planktonic $S$. epidermidis and disrupt $S$. epidermidis biofilm. ROS are known to cause protein and DNA damage and thus lead to bacteria death, but extracellular matrix protects the bacteria inside the biofilm from being exposed to $\operatorname{ROS}^{63}$. Thus, ROS alone might not be sufficient to kill bacteria inside the biofilm. The disruption of $S$. epidermidis biofilm in this study suggested that $\mathrm{nMgO}$ might have other mechanisms of action in addition to ROS or binding to cell membrane of the bacteria. MgO nanoparticles could possibly chelate with proteins and enzymes to disrupt the extracellular matrix, or act as a catalyst to degrade the extracellular matrix of the biofilm. MgO nanoparticles could also diffuse through the water channels in the biofilm matrix and disrupt the internal structure of biofilm. This is the first report on the capability of $\mathrm{MgO}$ nanoparticles in targeting and disrupting biofilms; and further studies on the exact mechanisms of nMgO disrupting biofilms are still needed. Different mechanisms of nMgO against planktonic bacteria, yeasts and biofilms are proposed but not fully understood yet. Future studies should focus on mechanistic interactions of $\mathrm{nMgO}$ with various pathogenic microorganisms in planktonic forms or in biofilms.

\section{Conclusions}

Magnesium oxide nanoparticles ( $\mathrm{nMgO}$ ) exhibited inhibitory and bactericidal/fungicidal effects on the prevalent pathogenic bacteria and yeasts, as summarized in Table 2 . These results are directly comparable across all the microorganisms being studied because we used the consistent experimental methods, the same nMgO in size and shape, and the same initial seeding density for each microorganism of interest. Characterization of cell viability, adhesion and morphology after exposure to $\mathrm{nMgO}$ suggested that the $\mathrm{nMgO}$ could have different antimicrobial mechanisms against different types of bacteria and yeasts. The increase in broth $\mathrm{pH}$ and $\mathrm{Mg}^{2+}$ ion concentrations induced by $\mathrm{nMgO}$ dissociation was not the main mechanism of killing. The interactions of $\mathrm{nMgO}$ with cell wall and/or cell membrane could be the key mechanism for the lethal effects of nMgO against planktonic bacteria. The $\mathrm{nMgO}$ was able to eliminate gram-negative bacteria more effectively than gram-positive bacteria, possibly because of the differences in the structures of bacterial cell wall and membrane. This study demonstrated for the first time that $\mathrm{nMgO}$ disrupted S. epidermidis biofilm, suggesting there might be other mechanisms for $\mathrm{nMgO}$ to be antimicrobial. Further research is still needed to determine the exact mechanisms for the bactericidal/fungicidal effects of $\mathrm{nMgO}$ against the pathogenic bacteria and yeasts, in order to take full advantage of $\mathrm{nMgO}$ for a wide range of applications. This article provides valuable information on $\mathrm{nMgO}$ as an antimicrobial biomaterial for engineering infection-free medical devices and implants in the future. 


\section{Data Availability}

All data generated or analyzed during this study are included in this published article and its Supplementary Information files.

\section{References}

1. Perl, T. M. et al. Intranasal mupirocin to prevent postoperative Staphylococcus aureus infections. New England Journal of Medicine 346, 1871-1877 (2002).

2. Gao, G. et al. The biocompatibility and biofilm resistance of implant coatings based on hydrophilic polymer brushes conjugated with antimicrobial peptides. Biomaterials 32, 3899-3909 (2011).

3. Bryers, J. D. Medical biofilms. Biotechnology and bioengineering 100, 1-18 (2008).

4. Aslam, S. Effect of antibacterials on biofilms. American journal of infection control 36, S175. e179-S175. e111 (2008).

5. Ramage, G., Mowat, E., Jones, B., Williams, C. \& Lopez-Ribot, J. Our current understanding of fungal biofilms. Critical reviews in microbiology 35, 340-355 (2009).

6. Lynch, A. S. \& Robertson, G. T. Bacterial and fungal biofilm infections. Annu. Rev. Med. 59, 415-428 (2008).

7. Zimmerli, W., Trampuz, A. \& Ochsner, P. E. Prosthetic-joint infections. New England Journal of Medicine 351, 1645-1654 (2004).

8. Donlan, R. M. Biofilms and device-associated infections. Emerging infectious diseases 7, 277 (2001).

9. Peasah, S. K., McKay, N. L., Harman, J. S., Al-Amin, M. \& Cook, R. L. Medicare non-payment of hospital-acquired infections: infection rates three years post implementation. Medicare \& medicaid research review 3 (2013).

10. Dizaj, S. M., Lotfipour, F., Barzegar-Jalali, M., Zarrintan, M. H. \& Adibkia, K. Antimicrobial activity of the metals and metal oxide nanoparticles. Materials Science and Engineering: C 44, 278-284 (2014).

11. Jones, N., Ray, B., Ranjit, K. T. \& Manna, A. C. Antibacterial activity of ZnO nanoparticle suspensions on a broad spectrum of microorganisms. FEMS microbiology letters 279, 71-76 (2008).

12. Foster, H. A., Ditta, I. B., Varghese, S. \& Steele, A. Photocatalytic disinfection using titanium dioxide: spectrum and mechanism of antimicrobial activity. Applied microbiology and biotechnology 90, 1847-1868 (2011).

13. Rai, M., Yadav, A. \& Gade, A. Silver nanoparticles as a new generation of antimicrobials. Biotechnology advances 27, 76-83 (2009).

14. Sawai, J. et al. Antibacterial characteristics of magnesium oxide powder. World Journal of Microbiology and Biotechnology 16, 187-194 (2000).

15. Jin, T. \& He, Y. Antibacterial activities of magnesium oxide (MgO) nanoparticles against foodborne pathogens. Journal of Nanoparticle Research 13, 6877-6885 (2011).

16. Stoimenov, P. K., Klinger, R. L., Marchin, G. L. \& Klabunde, K. J. Metal oxide nanoparticles as bactericidal agents. Langmuir 18, 6679-6686 (2002).

17. Krishnamoorthy, K., Manivannan, G., Kim, S. J., Jeyasubramanian, K. \& Premanathan, M. Antibacterial activity of MgO nanoparticles based on lipid peroxidation by oxygen vacancy. Journal of Nanoparticle Research 14, 1063 (2012).

18. Wetteland, C. L., Nguyen, N.-Y. T. \& Liu, H. Concentration-dependent behaviors of bone marrow derived mesenchymal stem cells and infectious bacteria toward magnesium oxide nanoparticles. Acta biomaterialia 35, 341-356 (2016).

19. Tang, Z. X. \& Lv, B. F. MgO Nanoparticles As Antibacterial Agent: Preparation And Activity. Braz J Chem Eng 31, 591-601, https:// doi.org/10.1590/0104-6632.20140313s00002813 (2014).

20. Healey, K. R., et al Prevalent mutator genotype identified in fungal pathogen Candida glabrata promotes multi-drug resistance. 7 , 11128, https://doi.org/10.1038/ncomms11128, https://www.nature.com/articles/ncomms11128\#supplementary-information (2016).

21. Taylor, P., Schoenknecht, F., Sherris, J. \& Linner, E. Determination of minimum bactericidal concentrations of oxacillin for Staphylococcus aureus: influence and significance of technical factors. Antimicrobial Agents and Chemotherapy 23, 142-150 (1983).

22. Barry, A. L. et al Methods for determining bactericidal activity of antimicrobial agents: approved guideline. NCCLS document M26-A 19 (1999).

23. Koul, A. et al. Diarylquinolines are bactericidal for dormant mycobacteria as a result of disturbed ATP homeostasis. Journal of Biological Chemistry 283, 25273-25280 (2008).

24. Rao, S. P., Alonso, S., Rand, L., Dick, T. \& Pethe, K. The protonmotive force is required for maintaining ATP homeostasis and viability of hypoxic, nonreplicating Mycobacterium tuberculosis. Proceedings of the National Academy of Sciences 105, 11945-11950 (2008).

25. Nicolle, L. E. Urinary catheter-associated infections. Infectious disease clinics of North America 26, 13-27 (2012).

26. Campoccia, D., Montanaro, L. \& Arciola, C. R. The significance of infection related to orthopedic devices and issues of antibiotic resistance. Biomaterials 27, 2331-2339 (2006).

27. Makhluf, S. et al. Microwave-Assisted Synthesis of Nanocrystalline MgO and Its Use as a Bacteriocide. Advanced Functional Materials 15, 1708-1715 (2005).

28. Yanagisawa, Y. \& Huzimura, R. Interaction of Oxygen Molecules with Surface Centers of UV-Irradiated MgO. Journal of the Physical Society of Japan 50, 209-216 (1981).

29. Tian, Q. \& Liu, H. Electrophoretic deposition and characterization of nanocomposites and nanoparticles on magnesium substrates. Nanotechnology 26, 175102 (2015).

30. Sudbery, P., Gow, N. \& Berman, J. The distinct morphogenic states of Candida albicans. Trends in microbiology 12, 317-324 (2004).

31. Slonczewski, J. L. \& Foster, J. W. Microbiology: An Evolving Science: Third International Student Edition. (WW Norton \& Company, 2013).

32. Gu, X., Sun, Y., Tu, K., Dong, Q. \& Pan, L. Predicting the growth situation of Pseudomonas aeruginosa on agar plates and meat stuffs using gas sensors. Scientific reports 6 (2016).

33. Weinstein, R. A. \& Darouiche, R. O. Device-associated infections: a macroproblem that starts with microadherence. Clinical Infectious Diseases 33, 1567-1572 (2001).

34. Merritt, J. H., Kadouri, D. E. \& O'Toole, G. A. Growing and analyzing static biofilms. Current protocols in microbiology, 1B. 1.1-1B. $1.18(2005)$

35. Brown, D. \& Salt, F. The mechanism of electrophoretic deposition. Journal of Chemical Technology and Biotechnology 15, 40-48 (1965).

36. Fidel, P. L., Vazquez, J. A. \& Sobel, J. D. Candida glabrata: review of epidemiology, pathogenesis, and clinical disease with comparison to C. albicans. Clinical microbiology reviews 12, 80-96 (1999).

37. Monzavi, A., Eshraghi, S., Hashemian, R. \& Momen-Heravi, F. In vitro and ex vivo antimicrobial efficacy of nano-MgO in the elimination of endodontic pathogens. Clinical oral investigations 19, 349-356 (2015).

38. Agnihotri, S., Mukherji, S. \& Mukherji, S. Size-controlled silver nanoparticles synthesized over the range 5-100 nm using the same protocol and their antibacterial efficacy. RSC Advances 4, 3974-3983 (2014).

39. Miller, M. B. \& Bassler, B. L. Quorum sensing in bacteria. Annu Rev Microbiol 55, 165-199, https://doi.org/10.1146/annurev. micro.55.1.165 (2001).

40. Coulthard, M. G. et al. Redefining urinary tract infections by bacterial colony counts. Pediatrics 125, 335-341 (2010).

41. Francolini, I. \& Donelli, G. Prevention and control of biofilm-based medical-device-related infections. FEMS Immunology \& Medical Microbiology 59, 227-238 (2010).

42. Lipke, P. N. \& Ovalle, R. Cell wall architecture in yeast: new structure and new challenges. Journal of bacteriology 180, 3735-3740 (1998).

43. Albertson, G. D., Niimi, M., Cannon, R. D. \& Jenkinson, H. F. Multiple efflux mechanisms are involved in Candida albicans fluconazole resistance. Antimicrobial Agents and Chemotherapy 40, 2835-2841 (1996). 
44. Odds, F. C., Brown, A. J. \& Gow, N. A. Antifungal agents: mechanisms of action. Trends in microbiology 11, 272-279 (2003).

45. Stevens, D. A., Espiritu, M. \& Parmar, R. Paradoxical effect of caspofungin: reduced activity against Candida albicans at high drug concentrations. Antimicrobial agents and chemotherapy 48, 3407-3411 (2004).

46. Pfaller, M. et al. Frequency of decreased susceptibility and resistance to echinocandins among fluconazole-resistant bloodstream isolates of Candida glabrata. Journal of clinical microbiology 50, 1199-1203 (2012).

47. Diekema, D., Arbefeville, S., Boyken, L., Kroeger, J. \& Pfaller, M. The changing epidemiology of healthcare-associated candidemia over three decades. Diagnostic microbiology and infectious disease 73, 45-48 (2012).

48. Lewis, J. S., Wiederhold, N. P., Wickes, B. L., Patterson, T. F. \& Jorgensen, J. H. Rapid emergence of echinocandin resistance in Candida glabrata resulting in clinical and microbiologic failure. Antimicrobial agents and chemotherapy 57, 4559-4561 (2013).

49. Alexander, B. D. et al. Increasing echinocandin resistance in Candida glabrata: clinical failure correlates with presence of FKS mutations and elevated minimum inhibitory concentrations. Clinical infectious diseases 56, (1724-1732 (2013).

50. Buttenschoen, K., Radermacher, P. \& Bracht, H. Endotoxin elimination in sepsis: physiology and therapeutic application. Langenbeck's archives of surgery 395, 597-605 (2010).

51. Kirikae, T., Nakano, M. \& Morrison, D. C. Antibiotic-induced endotoxin release from bacteria and its clinical significance. Microbiology and immunology 41, 285-294 (1997).

52. Leung, Y. H. et al. Mechanisms of antibacterial activity of MgO: non-ROS mediated toxicity of MgO nanoparticles towards Escherichia coli. Small 10, 1171-1183 (2014).

53. Clements, M. O., Watson, S. P. \& Foster, S. J. Characterization of the major superoxide dismutase of Staphylococcus aureus and its role in starvation survival, stress resistance, and pathogenicity. Journal of bacteriology 181, 3898-3903 (1999).

54. Karavolos, M. H., Horsburgh, M. J., Ingham, E. \& Foster, S. J. Role and regulation of the superoxide dismutases of Staphylococcus aureus. Microbiology 149, 2749-2758 (2003)

55. Neuhaus, F. C. \& Baddiley, J. A continuum of anionic charge: structures and functions of D-alanyl-teichoic acids in gram-positive bacteria. Microbiology and Molecular Biology Reviews 67, 686-723 (2003).

56. Reading, N. C. \& Sperandio, V. Quorum sensing: the many languages of bacteria. FEMS Microbiol Lett 254, 1-11, https://doi. org/10.1111/j.1574-6968.2005.00001.x (2006).

57. Sifri, C. D. Healthcare epidemiology: quorum sensing: bacteria talk sense. Clin Infect Dis 47, 1070-1076, https://doi. org/10.1086/592072 (2008).

58. Czaran, T. \& Hoekstra, R. F. Microbial communication, cooperation and cheating: quorum sensing drives the evolution of cooperation in bacteria. PLoS One 4, e6655, https://doi.org/10.1371/journal.pone.0006655 (2009)

59. Galloway, W. R., Hodgkinson, J. T., Bowden, S. D., Welch, M. \& Spring, D. R. Quorum sensing in Gram-negative bacteria: smallmolecule modulation of AHL and AI-2 quorum sensing pathways. Chem Rev 111, 28-67, https://doi.org/10.1021/cr100109t (2011).

60. Morohoshi, T. et al. Inhibition of quorum sensing in gram-negative bacteria by alkylamine-modified cyclodextrins. J Biosci Bioeng 116, 175-179, https://doi.org/10.1016/j.jbiosc.2013.01.022 (2013).

61. Holm, A. \& Vikstrom, E. Quorum sensing communication between bacteria and human cells: signals, targets, and functions. Front Plant Sci 5, 309, https://doi.org/10.3389/fpls.2014.00309 (2014).

62. Pfaller, M. A. Antifungal drug resistance: mechanisms, epidemiology, and consequences for treatment. The American journal of medicine 125, S3-S13 (2012).

63. Van Acker, H., Van Dijck, P. \& Coenye, T. Molecular mechanisms of antimicrobial tolerance and resistance in bacterial and fungal biofilms. Trends in microbiology 22, 326-333 (2014).

\section{Acknowledgements}

The authors thank the partial support from the U.S. National Science Foundation (Award 1512764, 1545852), the Hellman Faculty Fellowship (Huinan Liu), the U.S. National Institutes of Health (5R03AR069373, 6R43DE023287 and 2R44DE023287), the University of California (UC) Regents Faculty Development Award (Huinan Liu), and the U.S. Department of Education (the STEM Pathways Program, P031C110131) for supporting undergraduate researcher (N.G.). The authors appreciate the Central Facility for Advanced Microscopy and Microanalysis (CFAMM) for the use of Nova NanoSEM 450 at the University of California at Riverside. The authors thank Qiaomu Tian for assisting the particle analysis, Dr. Yadong Yin for using the particle analyzer, Dr. Jill P. AdlerMoore for providing the stocks of microorganisms, and Dylan Enright for helpful discussion. The content is solely the responsibility of the authors and does not necessarily represent the official views of the National Science Foundation or the National Institutes of Health

\section{Author Contributions}

H.L. and N.N. designed the experiments; N.N., N.G., C.W. and R.R. conducted the experiments; H.L. and N.N. analyzed the data, prepared all figures and wrote the main manuscript text. All authors reviewed the manuscript.

\section{Additional Information}

Supplementary information accompanies this paper at https://doi.org/10.1038/s41598-018-34567-5.

Competing Interests: The authors declare no competing interests.

Publisher's note: Springer Nature remains neutral with regard to jurisdictional claims in published maps and institutional affiliations.

Open Access This article is licensed under a Creative Commons Attribution 4.0 International License, which permits use, sharing, adaptation, distribution and reproduction in any medium or format, as long as you give appropriate credit to the original author(s) and the source, provide a link to the Creative Commons license, and indicate if changes were made. The images or other third party material in this article are included in the article's Creative Commons license, unless indicated otherwise in a credit line to the material. If material is not included in the article's Creative Commons license and your intended use is not permitted by statutory regulation or exceeds the permitted use, you will need to obtain permission directly from the copyright holder. To view a copy of this license, visit http://creativecommons.org/licenses/by/4.0/.

(C) The Author(s) 2018 